National Water-Quality Assessment (NAWOA) Program

\title{
Identifying Hydrologic Processes in Agricultural Watersheds Using Precipitation-Runoff Models
}
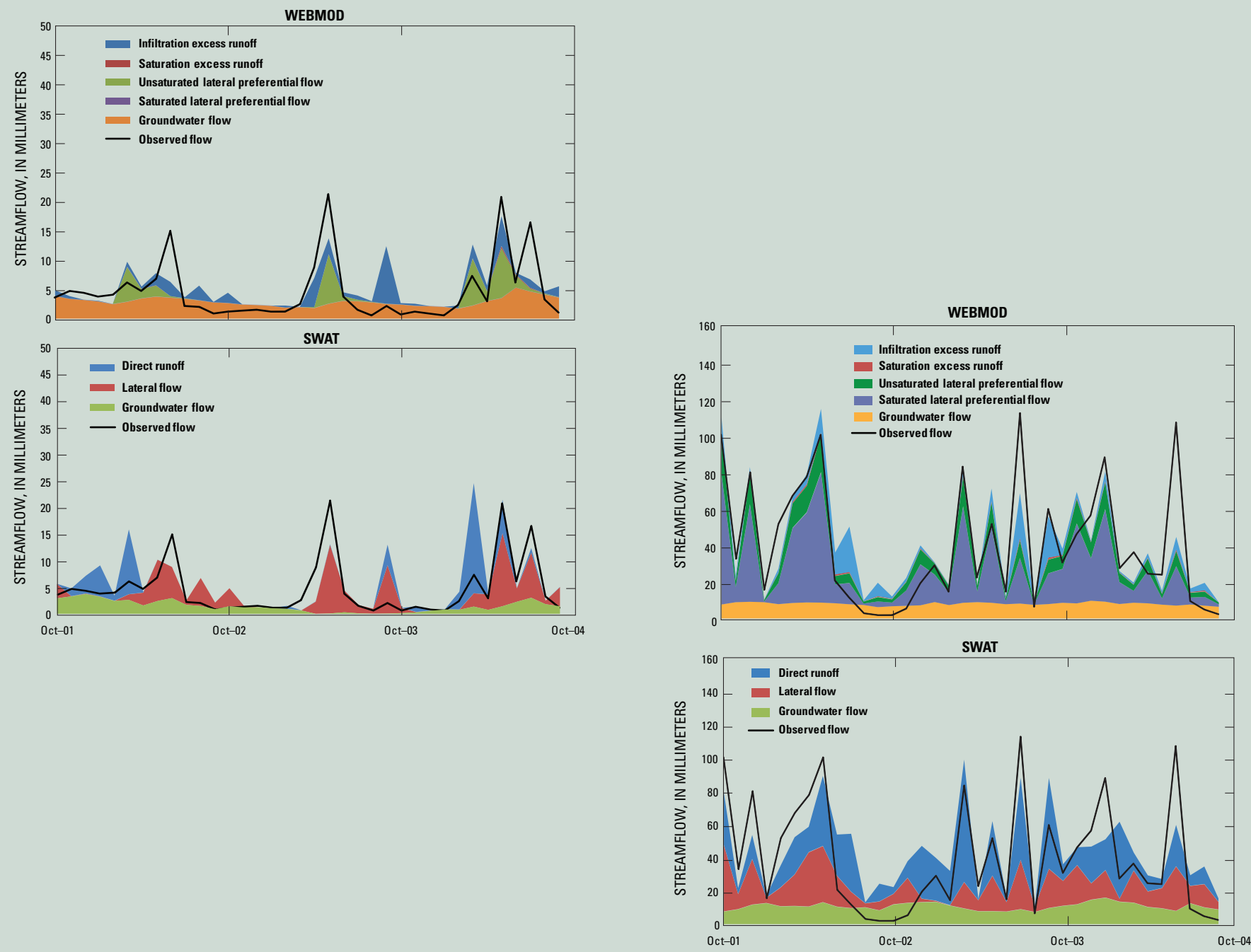

Scientific Investigations Report 2009-5126 

National Water-Quality Assessment (NAWOA) Program

\section{Identifying Hydrologic Processes in Agricultural Watersheds Using Precipitation-Runoff Models}

By Joshua I. Linard, David M. Wolock, Richard M.T. Webb, and Michael E. Wieczorek

Scientific Investigations Report 2009-5126 


\title{
U.S. Department of the Interior \\ KEN SALAZAR, Secretary
}

\author{
U.S. Geological Survey \\ Suzette M. Kimball, Acting Director
}

U.S. Geological Survey, Reston, Virginia: 2009

For more information on the USGS - the Federal source for science about the Earth, its natural and living resources, natural hazards, and the environment, visit http://www.usgs.gov or call 1-888-ASK-USGS

For an overview of USGS information products, including maps, imagery, and publications, visit http://www.usgs.gov/pubprod

To order this and other USGS information products, visit http://store.usgs.gov

Any use of trade, product, or firm names is for descriptive purposes only and does not imply endorsement by the U.S. Government.

Although this report is in the public domain, permission must be secured from the individual copyright owners to reproduce any copyrighted materials contained within this report.

Suggested citation:

Linard, J.I., Wolock, D.M., Webb, R.M.T., and Wieczorek, M.E., 2009, Identifying hydrologic processes in agricultural watersheds using precipitation-runoff models: U.S. Geological Survey Scientific Investigations Report 2009-5126, $22 \mathrm{p}$. 


\section{Contents}

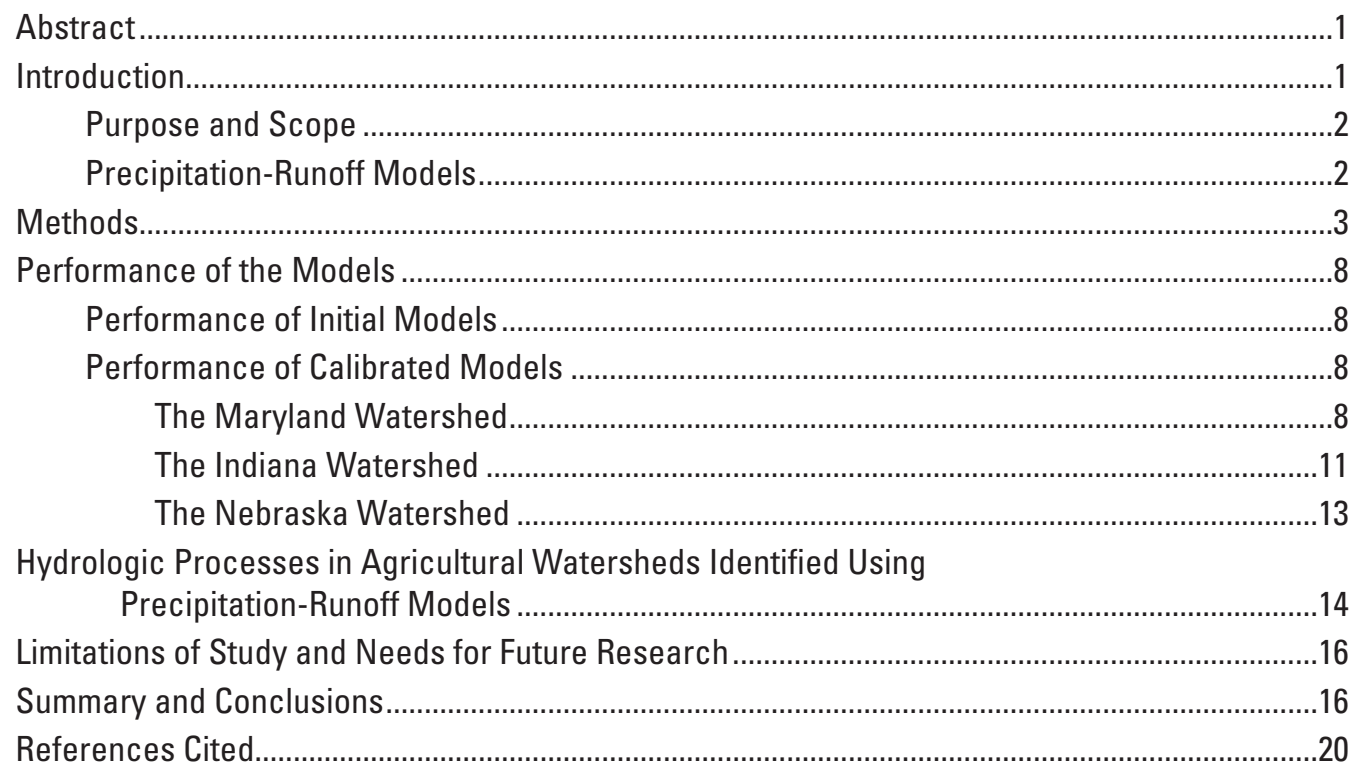

\section{Figures}

1. Maps showing the Soil and Water Assessment Tool (SWAT) hillslopes and Water, Energy, and Biogeochemical MODel (WEBMOD) subbasins for the

$(A)$ Maryland watershed, $(B)$ Indiana watershed, and $(C)$ Nebraska watershed ..............4

2-7. Graphs showing:

2. Observed and simulated streamflow in the Maryland watershed for water year 1998

3. Observed and simulated streamflow in the Indiana watershed for water year 1998

4. Observed and simulated streamflow in the Nebraska watershed for water year 1997

5. Contributions to streamflow from validated Soil and Water Assessment

Tool (SWAT) and Water, Energy, and Biogeochemical MODel (WEBMOD)

models for the Maryland watershed

6. Contributions to streamflow from validated Soil and Water Assessment Tool (SWAT) and Water, Energy, and Biogeochemical MODel (WEBMOD) models for the Indiana watershed

7. Contributions to streamflow from validated Soil and Water Assessment Tool (SWAT) and Water, Energy, and Biogeochemical MODel (WEBMOD) models for the Nebraska watershed 


\section{Tables}

1. Spatial representation of the Maryland, Indiana, and Nebraska watersheds for the Soil and Water Assessment Tool (SWAT) and Water, Energy, and Biogeochemical MODel (WEBMOD) models.

2. Statistical results of initial Soil and Water Assessment Tool (SWAT) and Water, Energy, and Biogeochemical MODel (WEBMOD) simulations

3. Parameters changed during calibration for SWAT models developed for the Maryland, Indiana, and Nebraska watersheds

4. Parameters changed during calibration for WEBMOD models developed for the Maryland, Indiana, and Nebraska watersheds

5. Statistical evaluation of calibrated and validated Soil and Water Assessment Tool (SWAT) and Water, Energy, and Biogeochemical MODel (WEBMOD) models for the Maryland watershed

6. Statistical evaluation of calibrated and validated Soil and Water Assessment Tool (SWAT) and Water, Energy, and Biogeochemical MODel (WEBMOD) models for the Indiana watershed.

7. Statistical evaluation of calibrated and validated Soil and Water Assessment Tool (SWAT) and Water, Energy, and Biogeochemical MODel (WEBMOD) models for the Nebraska watershed.

8. Contributions to streamflow from Soil and Water Assessment Tool (SWAT) and Water, Energy, and Biogeochemical MODel (WEBMOD) simulations for the validation period. 


\section{Conversion Factors}

\begin{tabular}{lcl}
\hline Multiply & \multicolumn{1}{c}{ By } & To obtain \\
\hline & \multicolumn{1}{c}{ Length } \\
\hline centimeter $(\mathrm{cm})$ & 0.3937 & inch \\
millimeter $(\mathrm{mm})$ & 0.03937 & inch \\
meter $(\mathrm{m})$ & 1.094 & yard \\
\hline \multicolumn{2}{c}{ Area } & \\
\hline square kilometer $\left(\mathrm{km}^{2}\right)$ & $247.1 \quad$ acre \\
square kilometer $\left(\mathrm{km}^{2}\right)$ & 0.3861 & square mile \\
\hline & \multicolumn{2}{c}{ Flow rate } \\
\hline centimeter per hour $(\mathrm{cm} / \mathrm{hr})$ & 0.3937 & inch per hour $(\mathrm{in} / \mathrm{hr})$ \\
\hline
\end{tabular}

Temperature in degrees Celsius $\left({ }^{\circ} \mathrm{C}\right)$ may be converted to degrees Fahrenheit $\left({ }^{\circ} \mathrm{F}\right)$ as follows:

$$
{ }^{\circ} \mathrm{F}=\left(1.8 \times{ }^{\circ} \mathrm{C}\right)+32
$$

Vertical coordinate information is referenced to the North American Vertical Datum of 1988 (NAVD 88).

Horizontal coordinate information is referenced to the, North American Datum of 1983 (NAD 83).

Altitude, as used in this report, refers to distance above the vertical datum.

Water Year (WY) is defined as beginning 0ctober 1 and continuing through September 30 of the following year. 



\title{
Identifying Hydrologic Processes in Agricultural Watersheds Using Precipitation-Runoff Models
}

\author{
By Joshua I. Linard, David M. Wolock, Richard M.T. Webb, and Michael E. Wieczorek
}

\section{Abstract}

Understanding the fate and transport of agricultural chemicals applied to agricultural fields will assist in designing the most effective strategies to prevent water-quality impairments. At a watershed scale, the processes controlling the fate and transport of agricultural chemicals are generally understood only conceptually. To examine the applicability of conceptual models to the processes actually occurring, two precipitation-runoff models - the Soil and Water Assessment Tool (SWAT) and the Water, Energy, and Biogeochemical Model (WEBMOD) — were applied in different agricultural settings of the contiguous United States. Each model, through different physical processes, simulated the transport of water to a stream from the surface, the unsaturated zone, and the saturated zone. Models were calibrated for watersheds in Maryland, Indiana, and Nebraska. The calibrated sets of input parameters for each model at each watershed are discussed, and the criteria used to validate the models are explained.

The SWAT and WEBMOD model results at each watershed conformed to each other and to the processes identified in each watershed's conceptual hydrology. In Maryland the conceptual understanding of the hydrology indicated groundwater flow was the largest annual source of streamflow; the simulation results for the validation period confirm this. The dominant source of water to the Indiana watershed was thought to be tile drains. Although tile drains were not explicitly simulated in the SWAT model, a large component of streamflow was received from lateral flow, which could be attributed to tile drains. Being able to explicitly account for tile drains, WEBMOD indicated water from tile drains constituted most of the annual streamflow in the Indiana watershed. The Nebraska models indicated annual streamflow was composed primarily of perennial groundwater flow and infiltration-excess runoff, which conformed to the conceptual hydrology developed for that watershed. The hydrologic processes represented in the parameter sets resulting from each model were comparable at individual watersheds, but varied between watersheds. The models were unable to show, however, whether hydrologic processes other than those included in the original conceptual models were major contributors to streamflow. Supplemental simulations of agricultural chemical transport could improve the ability to assess conceptual models.

\section{Introduction}

Agricultural chemical transport from point and nonpoint sources is one of the leading impairments to water quality in rivers and lakes (Parry, 1998). To alleviate the impairments induced by agricultural chemicals, much research has focused on improving the understanding of relations between the application areas, the media through which the chemicals travel, and the final receptor where the chemicals can impair beneficial uses. A receptor can consist of any reservoir of water, such as a stream, lake, aquifer, or the unsaturated zone. It has become apparent that understanding the spatial distribution of agricultural chemical sources and the resulting drainage to a receptor is essential to the design or implementation of practices that will effectively improve water quality (Edwards and others, 1997; Leu and others, 2005). Factors that complicate the understanding of agricultural chemical transport include the inherent spatial variability of the media through which the agricultural chemicals travel and anthropogenic factors associated with agricultural areas (Carluer and De Marsily, 2004; Moussa and others, 2002; Green and others, 2006).

As Moore and others (1991) indicate, the transport of agricultural chemicals through an area of interest (for example, from a hillslope to a receptor such as a stream or groundwater system) is controlled almost exclusively by the movement of water. A conceptual model of the processes governing that movement of water can be developed on the basis of field observations. Generally, the number of processes or paths by which water can reach a stream is small. Surface runoff is generated when the precipitation rate exceeds the infiltration rate of the surface soil. Surface runoff also is generated when precipitation falls on a saturated soil. Prior to reaching the water table, water can enter a stream by preferential lateral flow or by lateral return flow from a perched, saturated soil matrix. Groundwater can contribute to streamflow through the streambed or where the water table intersects the streambank and the water seeps from the banks before entering the stream. Although some studies have linked agricultural chemicals to specific water-quality impairment of receptors, few studies have holistically assessed the function of the transport media in the processes used to transport chemicals to the receptor (Fenelon and Moore, 1998; Hyer and others, 2001; Leu and others, 2004). 
Due to the difficulties associated with accounting for the spatial variability of agricultural chemical transport through field measurements, numerical models for numerous environmental processes have been developed as an alternative means of accounting for spatial variability (National Research Council, 2002; Shaffer and Delgado, 2001). For example, an environmental process that helps regulate the transport of agricultural chemicals is the spatially variable response of the land surface to precipitation. A common method of accounting for this variability is the curve number $(\mathrm{CN})$ method (McCuen, 1982), which partitions received rainfall into water available for either infiltration or direct runoff to the stream. Various $\mathrm{CNs}$ can be designated to different areas of a watershed and are generally based on land cover and soil type. Areas with greater soil moisture are commonly predicted to produce more runoff than drier soils. By simulating the response to rainfall of different CNs throughout a watershed, the spatial variability of soil moisture can be accounted for. Although this type of empirical relation is a means of accounting for the spatially variable response of the land surface to precipitation, when applied to an entire watershed it does not account for the generally accepted variable source area concept of runoff generation made known by Whipkey (1965) and Hewlett and Hibbert (1967).

Beven and Kirkby (1979) introduced the TOPography based hydrological MODEL (TOPMODEL), which mathematically represents the variable source area concept. In TOPMODEL, points in a watershed with similar upslope contributing areas and slopes are assumed to have similar depths to the water table and underlying aquifer materials with similar water-transmitting capacities. TOPMODEL algorithms have commonly been applied in humid, pristine watersheds where the water table is near land surface. Although applications of the algorithm to agricultural areas have been few, the ability of the TOPMODEL algorithm to simulate hydrologic processes is appealing for the purpose of determining the dominant hydrologic processes in agricultural landscapes. To improve understanding of how different hydrologic processes transport water through agricultural watersheds to streams, the U.S. Geological Survey (USGS) designed a study using two available precipitation-runoff models.

\section{Purpose and Scope}

This report describes applications of models developed for three different agricultural watersheds in different parts of the United States: the Maryland Watershed, the Indiana Watershed, and the Nebraska Watershed. Two precipitation-runoff (PR) models were used to identify different hydrologic processes that transport water to streams; one model used the CN method and the other used the TOPMODEL algorithm. The hydrologic processes identified by the models were then compared to corresponding processes in the conceptual models at each watershed. Through this comparison, a realistic picture of the hydrologic system, in terms of the relative importance of different pathways by which water was transported to the watershed outlet, was obtained. Inclusive to this discussion was the contrasting of the methods used by each model to simulate the hydrologic processes governing the movement of water to a stream from the land surface and through the unsaturated zone, saturated zone, and preferential flow paths. The methods used by each model to account for different agricultural management practices were also discussed.

\section{Precipitation-Runoff Models}

The Soil and Water Assessment Tool (SWAT) (version SWAT2000) (Neitsch and others, 2002; also see $h t t p: / / b r c$. tamus.edu/swat/ accessed April 28, 2009) uses the CN method to partition precipitation into either infiltration, which can then reach a stream by several flow paths, or to overland runoff, which flows directly to a stream. As the $\mathrm{CN}$ increases, a greater amount of precipitation is apportioned to direct runoff. Infiltrated water can reach a stream through shallow lateral return flow or through tile drains. Water percolating from the soil profile to the saturated zone can travel to a stream as groundwater flow or be lost to a deeper, regional groundwater system.

The Water, Energy, and Biogeochemical MODel (WEBMOD) (Webb and others, 2006) uses the TOPMODEL algorithm as its means of accounting for the spatially variable response of a watershed to precipitation. In addition to precipitation-excess runoff, infiltration-excess water that becomes overland flow also is simulated in WEBMOD. Within the WEBMOD structure, soil water that exceeds field capacity can move vertically downward and(or) flow laterally to a stream as preferential flow. Water that percolates from the soil profile that recharges the shallow aquifer can reach a stream through saturated preferential flow paths (for example, tile drains), by exfiltration, and by direct groundwater flow to a stream. Exfiltration represents water from the shallow aquifer that reaches the stream after it emerges on a hillslope as seeps where the water table intersects the land surface. A head-dependent loss parameter is used to account for ground-water losses from the saturated zone.

The differences in the way SWAT and WEBMOD account for hydrologic processes and land cover reflect the original goals in their model design. SWAT was designed to simulate the water draining from relatively flat areas with patches of distinct crops, whereas WEBMOD was designed to simulate streamflow generation in forested areas of high relief. As noted in Capel and others (2008), each model divides the study watershed into subbasins. Within SWAT each subbasin is further subdivided into Hydrologic Response Units (HRUs) based on differences in land cover or soils. Although HRUs lack spatial attributes, a unique hydrologic response is simulated from each.

WEBMOD isolates a subbasin into right and left hillslopes to be able to simulate different insolation on northfacing slopes compared to that on south-facing slopes. The 
hillslope hydrology is simulated, in part, on the basis of the dominant vegetation type, log-normal models for decreasing hydraulic conductivity and tranmissivity with depth, and discrete areas of similar topographic wetness index (TWI). The TWI areas on a hillslope are the smallest hydrologic units in WEBMOD. Although not explicitly connected, TWI values will be smallest on hilltops and greatest in riparian areas and wetlands. For each hillslope, computations of infiltration, evapotranspiration, recharge, and water-table fluctuations were carried out for 30 areas of similar TWI. Vegetation types in WEBMOD affect evapotranspiration and are limited to bare ground, grass, shrubs, and forest; the major distinction is the available canopy interception in summer compared to winter. In all WEBMOD models, crops were simulated as deciduous trees by using the "leaf-on" period typical of the modeled region.

\section{Methods}

SWAT and WEBMOD models were developed for each of the Maryland, Indiana, and Nebraska study watersheds by using the same spatial data inputs: a digital elevation model (DEM), a land-use grid, and a grid of soil map units. Thirty-meter resolution DEMs were obtained from the USGS Seamless Server (U.S. Geological Survey, 2006) and were hydrologically corrected using high-resolution stream coverages from the National Hydrography dataset (U.S. Geological Survey, 1999). For the Nebraska study site, a 33-m resolution DEM was used because of geographic information system (GIS) limitations. Subbasins (fig. 1) were created within each model (table 1) with the outlet of each subbasin being identical in the two models. Basin boundary delineations differed slightly due to the way the data preprocessors conditioned the DEM. Between the two models the areas of the individual subbasins and the total basin area were within 0.5 percent of each other.

Within subbasins created for the SWAT models, HRUs were created based on dominant land cover and soils. Multiple HRUs within a subbasin were determined if a land cover within a subbasin occupied more than 20 percent of the subbasin area and a soil type consisted of at least 10 percent of the subbasin area. These threshold values were chosen on the basis of experience with the model development, which indicated that when the chosen values exceeded those used (the 20 percent and 10 percent), the creation of multiple HRUs within a subbasin was unlikely. This upper threshold was used because Fitzhugh and Mackay (2000) indicated that an excess of HRUs could limit model performance. The National Land Cover Dataset (NLCD) (Vogelmann and others, 2001) land-cover data were used to determine HRUs in the Maryland and Indiana watersheds. For the Nebraska watershed the Cropland Data Layer (CDL) (United States Department of Agriculture-National Agricultural Statistics Service, 2002), which was unavailable for the Maryland and Indiana watersheds, was used in determining HRUs because it had separate classification for agricultural crops. In both the Maryland and Indiana watersheds the only land-cover classifications conforming to the criteria were row crops and pasture. Due to the more detailed land-cover information available for the Nebraska watershed, the row crop classification could be divided into classifications for corn and soybeans. The State Soil Geographic Database (STATSGO) (Schwarz and Alexander, 1995) was used in all watersheds for soil classifications. The 10-percent criteria for soils left four possible soil types in both the Maryland and Indiana watersheds and five in the Nebraska watershed. Not every combination of land cover and soil type existed in every SWAT subbasin; consequently, for some combinations, an HRU was not created. The varied land cover and soils yielded 6 HRUs in the Maryland watershed, 7 in the Indiana watershed, and 13 HRUs in the Nebraska watershed.

Default CNs were assigned by the SWAT models to each HRU on the basis of the combination of land cover and soil. HRUs with row crops in the Maryland watershed received a value of 78 , and 69 was the value given those classified as pasture. Indiana had identical land-cover classifications; however, differing soil hydrologic properties produced two CNs for row crops (78 and 85) and pasture (69 and 79). The different row crops in the Nebraska watershed produced a $\mathrm{CN}$ of 77 for corn, 78 for soybeans, and 69 for pasture.

The extent of climatic spatial variability in each of the study watersheds was evaluated by USGS hydrologists located in the State of each watershed. Single weather stations were deemed adequate to represent the precipitation and temperature for the Maryland and Indiana watersheds (Chestertown, Maryland, and Greenfield, Indiana). Precipitation and temperature data from seven weather stations (fig. 1C) in and around the Nebraska watershed were distributed spatially using the XYZ method described by Hay and McCabe (2002). This method is readily incorporated into models, such as WEBMOD, that have been developed within the framework of the USGS Modular Modeling System (MMS) (Leavesley and others, 1998). In SWAT, the climate for each subbasin is assumed to be adequately represented by data from the closest weather station; therefore, to ensure climatic inputs were consistent between models, the WEBMOD simulated precipitation and temperature were assigned to the Nebraska SWAT subbasins.

Precipitation-runoff models were created to simulate hydrology for daily time steps by using 19 years of daily observed temperature and precipitation from the aforementioned weather stations. Daily temperature and precipitation data were obtained from the U.S. Department of Commerce National Climatic Data Center (http://gis.ncdc.noaa.gov/ website/ims-cdo/sod/viewer.htm, accessed January 4, 2006). Streamflow data corresponding to the time period of the precipitation and temperature data were used to calibrate and validate the models. Daily streamflow for a stream gage located at the outlets of each watershed (Sugar Creek at New Palestine, Indiana, station number 03361650; Morgan Creek near Kennedyville, Maryland, station number 01493500; and Maple Creek near Nickerson, Nebraska, station number 


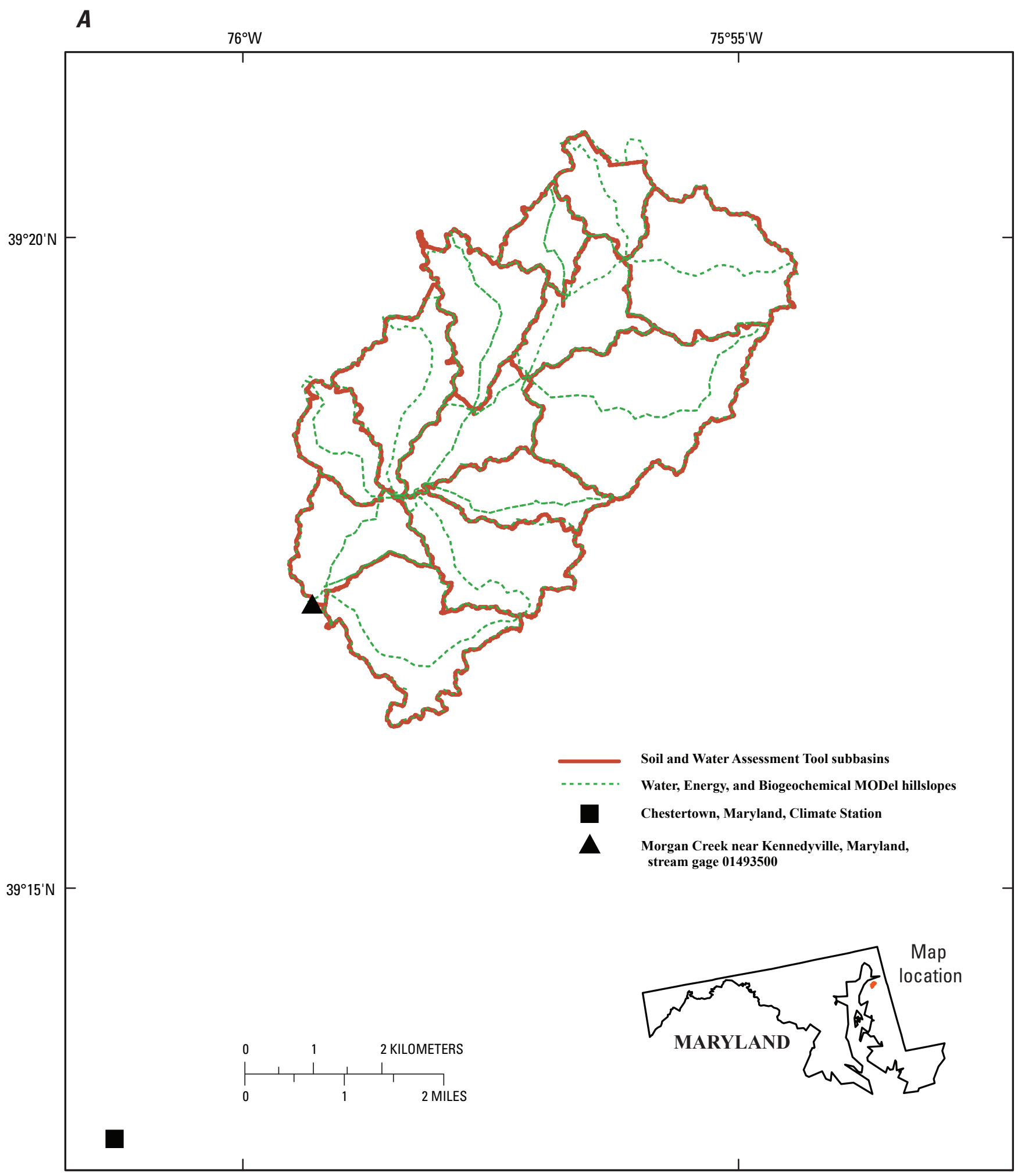

Figure 1. Water, Energy, and Biogeochemical MODel (WEBMOD) hillslopes and Soil and Water Assessment Tool (SWAT) subbasins for the $(A)$ Maryland watershed, $(B)$ Indiana watershed, and $(C)$ Nebraska watershed. 


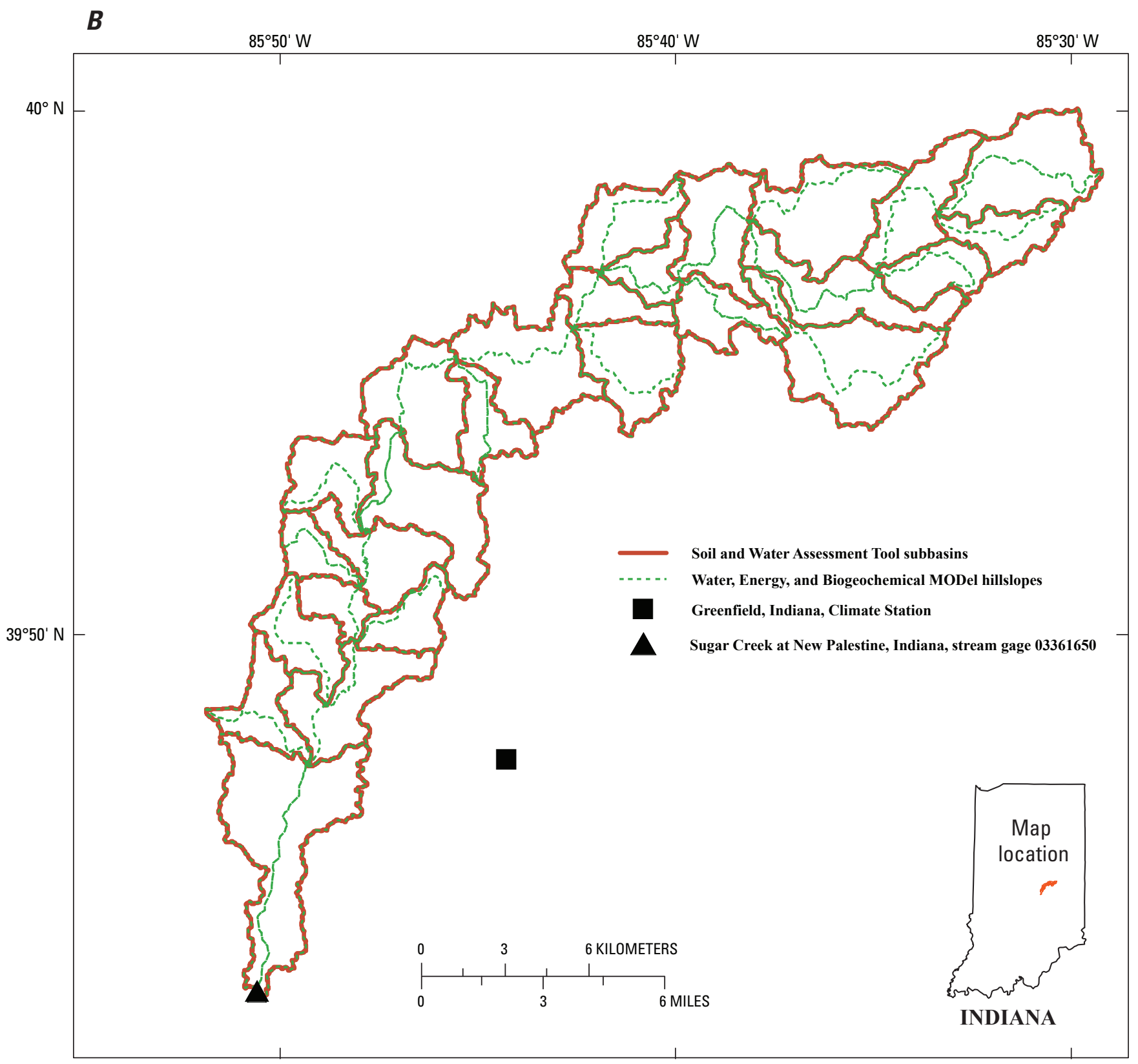

Figure 1. Water, Energy, and Biogeochemical MODel (WEBMOD) hillslopes and Soil and Water Assessment Tool (SWAT) subbasins for the $(A)$ Maryland watershed, $(B)$ Indiana watershed, and $(C)$ Nebraska watershed.-Continued 


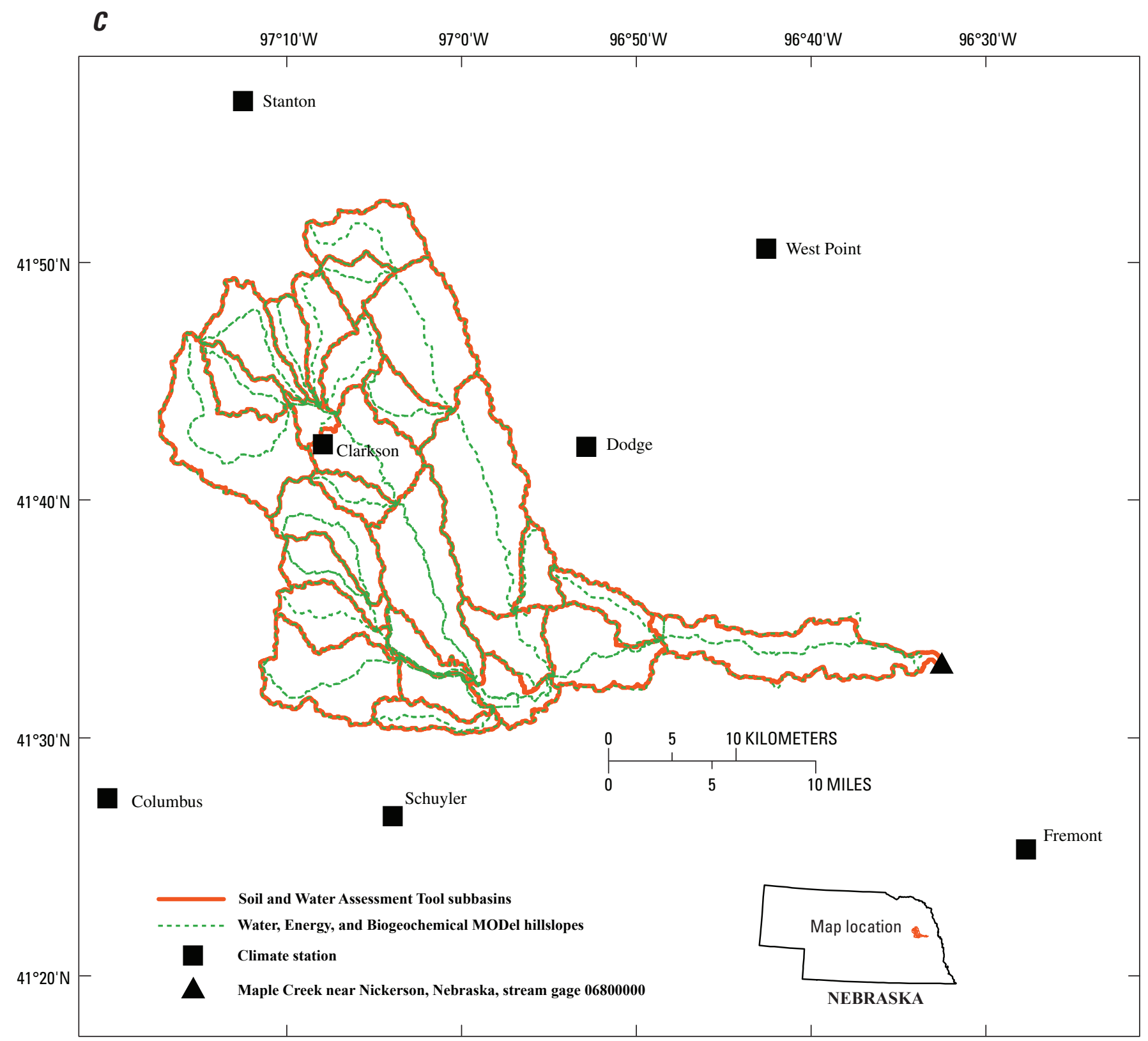

Figure 1. Water, Energy, and Biogeochemical MODel (WEBMOD) hillslopes and Soil and Water Assessment Tool (SWAT) subbasins for the $(A)$ Maryland watershed, $(B)$ Indiana watershed, and $(C)$ Nebraska watershed.-Continued 
Table 1. Spatial representation of the Maryland, Indiana, and Nebraska watersheds for the Soil and Water Assessment Tool (SWAT) and Water, Energy, and Biogeochemical MODel (WEBMOD) models.

\begin{tabular}{lccc}
\hline Watershed & $\begin{array}{c}\text { Watershed area } \\
\text { (square kilometers) }\end{array}$ & $\begin{array}{c}\text { Number of subbasins } \\
\text { (SWAT/WEBMOD) }\end{array}$ & $\begin{array}{c}\text { Mean SWAT subbasin } \\
\text { in areas } \\
\text { (square kilometers) }\end{array}$ \\
\hline Maryland & 33 & $13 / 26$ & 2.5 \\
Indiana & 249 & $26 / 52$ & 9.6 \\
Nebraska & 953 & $28 / 56$ & 34.0 \\
\hline
\end{tabular}

06800000) was obtained from the USGS National Water Information System (http://waterdata.usgs.gov/nwis/, accessed January 4, 2006). Throughout the report, streamflow will be reported in terms of depth of water, which is determined as the quotient of streamflow divided by basin area. Data for October 1985 through September 1987 were used to limit the effect of poor initial parameter values on simulations results, and the models were calibrated using daily data for October 1987 through September 1995. The models were then validated by using daily data for October 1996 through September 2004 as input parameters. In addition to calibrating the models to observed daily streamflow, the simulated mean annual actual evapotranspiration was compared to values reported in the literature. Mean annual actual evapotranspiration near the Maryland watershed was reported to be $770 \mathrm{~mm}$ (Sloto, 2002). Neitsch and others (2002) reported $700 \mathrm{~mm}$ of actual evapotranspiration at the Indiana watershed, and in Nebraska, Dugan and Zelt (2000) reported a mean annual evapotranspiration of about $500 \mathrm{~mm}$. The simulated evapotranspiration values, averaged over the 8-year calibration period, were deemed adequate if they were within 10 percent of the values reported in the literature.

Conceptual models included several hydrologic processes that governed the runoff response of each watershed. Field observations indicated that the mean depth to water at the Maryland watershed was 2 to $3 \mathrm{~m}$. Although groundwater was the dominant source of water contributing to streamflow in the Maryland watershed, infiltration-excess runoff was likely the source of observed peaks in streamflow. However, this surface runoff was believed to be retarded by the many retention ponds within the watershed. In addition, prior research by local USGS hydrologists indicates that about 2 percent $(20 \mathrm{~mm})$ of the annual precipitation is lost annually from the watershed as groundwater flow because a restrictive subsurface layer dips toward an adjacent watershed (Hancock and Brayton, 2006). Groundwater was likely to contribute to streamflow near the mouth of the Indiana watershed. The main source of annual streamflow and peak streamflow, however, was likely to be the discharge from tile drains buried at depths of 1.0 to $1.5 \mathrm{~m}$ beneath many of the fields in the watershed.

As much as 50 percent of the total volume of water discharged from the tile drains is estimated to do so during storms (Stone and Wilson, 2006; Lathrop, 2006). In the Nebraska watershed the depth to water in the headwaters of the watershed could be about $100 \mathrm{~m}$ (Fredrick and others, 2006). Sustained periods of low flow were observed in intermittent streams of the watershed, indicating that perched water tables can develop. This conceptualization was substantiated by field observations that indicated peaks in streamflow could only occur following an increase in near-surface soil moisture. Consequently, the hydrologic process responsible for peak streamflows is infiltration-excess runoff. Field observations also indicated that contributions to streamflow from regional groundwater flow generated perennial streamflow near the mouth of the Nebraska watershed.

The statistics used to evaluate the performance of the models included the Nash-Sutcliffe measure of efficiency (NSE), the ratio of the root mean square to the standard deviation of the observed data (RSR), and the percent bias (PBIAS) of the model (Moriasi and others, 2007). The NSE assesses the ability of a model to correctly simulate streamflow during periods when observed streamflow deviates largely from the mean streamflow and is calculated as:

$$
N S E=1-\left[\sum_{i=1}^{n}\left(Y_{i}^{\text {obs }}-Y_{i}^{s i m}\right)^{2} / \sum_{i=1}^{n}\left(Y_{i}^{\text {obs }}-Y^{\text {mean }}\right)^{2}\right],
$$

where $Y_{i}^{\text {obs }}$ is the observed streamflow for the ith timestep, $Y_{i}^{\text {sim }}$ is the simulated streamflow at the ith timestep, and $Y^{\text {mean }}$ is the mean observed streamflow. The total number of timesteps is indicated by $n$. A perfect model would produce an NSE of 1 ; however, Moriasi and others (2007) indicate that the performance of a model is considered to be "good" if the NSE is between 0.65 and 0.75 and "satisfactory" when the NSE is above 0.5 . 
The RSR evaluates the error associated with model performance and is determined from the root-mean square error (RMSE) and standard deviation (STDEV) in the observed data:

$$
R S R=\frac{R M S E}{S T D E V}=\frac{\left[\sqrt{\sum_{i=1}^{n}\left(Y_{i}^{\text {obs }}-Y_{i}^{\text {sim }}\right)^{2}}\right]}{\left[\sqrt{\sum_{i=1}^{n}\left(Y_{i}^{\text {obs }}-Y^{\text {mean }}\right)^{2}}\right]},
$$

where the factors are as defined in equation 1 .

A model performing with no error would produce an RSR of 0.0 . The criteria presented by Moriasi and others (2007) would designate model performance as "good" if the RSR ranges from 0.5 to 0.6 and "unsatisfactory" if the RSR were greater than 0.7 .

To evaluate the ability of the model to reproduce the streamflow component of the mass balance for an entire simulation, the PBIAS statistic was used and is calculated as:

$$
\text { PBIAS }=\frac{\sum_{i=1}^{n}\left(Y_{i}^{\text {obs }}-Y_{i}^{s i m}\right)}{\sum_{i=1}^{n}\left(Y_{i}^{\text {obs }}\right)}
$$

The PBIAS statistic can be positive or negative, but the closer to zero the value is, the closer the agreement between simulated and observed streamflow for the period being evaluated. A positive PBIAS value indicates the model is underpredicting streamflow, whereas negative values indicate overprediction. PBIAS values between \pm 10 and \pm 15 indicate a "good" model simulation, whereas values greater than \pm 25 indicate an "unsatisfactory" model simulation (Moriasi and others, 2007).

\section{Performance of the Models}

\section{Performance of Initial Models}

Input files created by the data preprocessors were used to develop initial models for October 1985 through September 1995. No parameters were adjusted, and no land-management practices were considered in the initial models. When determining statistics, the results of the first 2 years of each simulation were not included. The statistics determined from the initial SWAT and WEBMOD simulations for each watershed are given in table 2. Both models tended to overpredict large storm-event peaks and miss peaks resulting from small precipitation events. The observed base-flow conditions are typically much lower and show less fluctuation than those simulated. These tendencies of initial model performance are consistent with the results of initial simulations for the Indiana and Nebraska watersheds. NSE values did not exceed zero for any initial model except for the WEBMOD Indiana model, which produced a value of 0.36 . Nash-Sutcliffe values below zero indicated the mean streamflow for the period of record was a better predictor of streamflow than the model. The NSE values alone indicated the initial models for each watershed were unsatisfactory.

\section{Performance of Calibrated Models}

The SWAT and WEBMOD models were manually calibrated to improve their performance statistics. Although the parameters in each model represented different hydrologic theory, commonly each model required adjustments to better simulate the same hydrologic processes. In general, the parameters governing the infiltration of water through the root zone, the delay of groundwater movement from the saturated zone to the stream, and the evolution and melt of snow required changing. Standard changes could be made to each parameter on the basis of prior knowledge of the system being modeled. WEBMOD contained a parameter indicating the depth to bedrock or other restrictive layer, which could also be set on the basis of prior knowledge. Including these parameters, no more than 16 SWAT parameters (table 3) and 14 WEBMOD parameters (table 4) required changes to achieve calibrated models at each watershed. Simulation results from validated models produced statistical values similar to those of the calibration period.

\section{The Maryland Watershed}

The initial SWAT simulations for the Maryland watershed indicated a need to decrease streamflow contributions from direct runoff. The magnitude of direct runoff in the SWAT model was controlled using the $\mathrm{CN}$ value specific to each HRU. The CNs for each land cover (row crops and pasture) were decreased to the minimum values recommended by SWAT (Neitsch and others, 2002). In addition to adjusting the $\mathrm{CN}$ values, the available water-holding capacities of the soils were decreased so that they were similar to those reported by Meyer and others (1997). To improve the temporal relation between observed and simulated peak streamflows, water in stream channels was retained by decreasing the parameter controlling the surface runoff lag coefficient by 75 percent. In SWAT, decreases in the lag coefficient cause a decrease in the fraction of water available to move downstream. The improvement in model performance elicited from this change could implicitly represent the retention effects of the ponds within the watershed on streamflow generation. Following these adjustments, the magnitude and temporal distribution of simulated streamflow peaks were similar to those of the observed streamflow.

After calibrating to the runoff peaks in each model, attempts were made to match simulated base flow to observed periods of low flow. Complicating the calibration was the influence of a restrictive subsurface layer beneath the southern half of the watershed, which caused percolating water to drain 
Table 2. Statistical results of initial Soil and Water Assessment Tool (SWAT) and Water, Energy, and Biogeochemical MODel (WEBMOD) simulations.

\begin{tabular}{|c|c|c|c|c|c|c|}
\hline \multirow[t]{2}{*}{ Watershed } & \multicolumn{2}{|c|}{$\begin{array}{c}\text { Nash-Sutcliffe measure of } \\
\text { efficiency }\end{array}$} & \multicolumn{2}{|c|}{$\begin{array}{l}\text { Ratio of the root mean square } \\
\text { to the standard deviation of the } \\
\text { observed data }\end{array}$} & \multicolumn{2}{|c|}{ Percent bias } \\
\hline & SWAT & WEBMOD & SWAT & WEBMOD & SWAT & WEBMOD \\
\hline Maryland & -0.52 & -4.03 & 1.23 & 2.24 & -22.64 & -43.59 \\
\hline Indiana & -1.91 & 0.36 & 1.71 & 0.80 & -28.13 & -10.12 \\
\hline Nebraska & -1.05 & -0.28 & 1.43 & 1.13 & -37.81 & -78.76 \\
\hline
\end{tabular}

Table 3. Parameters changed during calibration for SWAT models developed for the Maryland, Indiana, and Nebraska watersheds.

[Multiple numbers indicate different values for different hydrologic response units (HRU). Changes are in bold. For more detailed parameter descriptions, see Neitsch and others (2002)]

\begin{tabular}{|c|c|c|c|c|}
\hline SWAT parameter & $\begin{array}{l}\text { Initial } \\
\text { value }\end{array}$ & Maryland & Indiana & Nebraska \\
\hline Curve number (CN2) & $\mathrm{CN}_{0}$ & $\mathrm{CN}_{0}-23 \%$ & $\mathrm{CN}_{0}-32 \%$ & $\mathrm{CN}_{0}-13 \%$ \\
\hline Hydraulic conductivity (SOL_K) & $\mathrm{K}_{0}$ & $\mathrm{~K}_{0}$ & $\mathrm{~K}_{0}$ & $K_{0}^{*} 100$ \\
\hline Available water capacity (SOL_AWC) & $\mathrm{AWC}_{0}$ & $\begin{array}{l}\mathrm{AWC}_{0}+0 \\
\text { and }+\mathbf{0 . 1}\end{array}$ & $\begin{array}{l}\mathrm{AWC}_{0} \\
+0.06\end{array}$ & $\begin{array}{r}\mathrm{AWC}_{0}+0.05 \\
\text { and }+0.1\end{array}$ \\
\hline Vertical preferential flow (ICRK) & 0 & 0 & 1 & 1 \\
\hline Main channel Manning's n (CH_N2) & 0.014 & 0.14 & $\mathbf{0 . 0 3}$ & 0.014 \\
\hline Subbasin Manning's n (CH_N1) & 0.014 & 0.014 & 0.14 & 0.014 \\
\hline HRU Manning's n (OV_N) & $0.14,0.15$ & $0.35,0.55$ & 0.44 & $0.44,0.6$ \\
\hline Lateral traveltime (LATTIME) & 0 & 1 & $1.5-4$ & 2 \\
\hline Slope length of the soils (SLSOIL) & 0 & 2 & 0.25 & 1 \\
\hline $\begin{array}{l}\text { Minimum amount of water in the shallow aquifer } \\
\text { required for groundwater flow (GWQMN) }\end{array}$ & 0 & 0 & 0 & $0, \mathbf{2 0 0}$ \\
\hline $\begin{array}{l}\text { Minimum amount of water in the shallow aquifer } \\
\text { required for evaporation to the root zone } \\
\text { (REVAPMN) }\end{array}$ & 1 & $\mathbf{0}$ & $\mathbf{0}$ & $\mathbf{0}$ \\
\hline $\begin{array}{l}\text { Coefficient limiting evaporation to the root zone } \\
\text { (GW_REVAP) }\end{array}$ & 0.02 & 0.04 & 0.07 & $0.02, \mathbf{0 . 0 4}$ \\
\hline Base-flow alpha factor (ALPHA_BF) & 0.048 & $0.048,0.1$ & $0.048, \mathbf{0 . 0 7 5}$ & $0.4,0.9$ \\
\hline Groundwater delay time (GW_DELAY) & 31 & 500 & $31-61$ & 31,210 \\
\hline Deep aquifer percolation fraction (RCHRG_DP) & 0.05 & $0-0.2$ & 0.2 & 0.05 \\
\hline Surface runoff lag coefficient (SURLAG) & 4 & 1 & 2 & 1 \\
\hline Snowfall temperature (SFTMP) & 1 & $\mathbf{0}$ & 1 & 1 \\
\hline Snowmelt temperature (SMTMP) & 0.5 & 2 & 0.5 & 0.5 \\
\hline Melt factor for snow on June 21 (SMFMX) & 4.5 & 3 & 4.5 & 4.5 \\
\hline Melt factor for snow on December 21 (SMFMN) & 4.5 & 1.5 & 1.5 & 4.5 \\
\hline $\begin{array}{l}\text { Minimum snow water equivalent equal to } 100 \% \\
\text { snow cover (SNOCOVMX) }\end{array}$ & 1 & 1 & 10 & 1 \\
\hline
\end{tabular}


Table 4. Parameters changed during calibration for WEBMOD models developed for the Maryland, Indiana, and Nebraska watersheds.

[Multiple numbers indicate different values for different hillslopes. Changes are in bold. For more detailed parameter, see Webb and others (2006)]

\begin{tabular}{|c|c|c|c|c|}
\hline WEBMOD parameter & Initial value & Maryland & Indiana & Nebraska \\
\hline Main channel routing velocity (chv) & 100 & 250 & 1,500 & 1,700 \\
\hline Minimum temperature for snowmelt (MBASE) & 32 & 32 & 38 & 38 \\
\hline Melt factor for snow on June 21 (MFMAX) & 0.6 & 0.5 & 1.6 & 1.6 \\
\hline Melt factor for snow on December 21 (MFMIN) & 0.2 & 0.2 & 0.3 & 0.3 \\
\hline $\begin{array}{l}\text { Fraction of potential infiltration that is preferentially routed to } \\
\text { the saturated zone (pmac_sat) }\end{array}$ & 0 & 0.05 & 0 & 0 \\
\hline $\begin{array}{l}\text { Fraction of percolation past the root zone that is preferentially } \\
\text { routed to the stream (qdffrac) }\end{array}$ & 0 & 0.28 & 0.2 & $0.2,0.5$ \\
\hline Depth to the restrictive layer (s_rock_depth) & 1.524 & 15 & 10 & 100 \\
\hline $\begin{array}{l}\text { Hydraulic conductivity of preferential flow through the } \\
\text { saturated zone (s_satpref_k) }\end{array}$ & 0 & 0 & 0.013 & 0 \\
\hline Soil field capacity (s_theta_fc) & $\mathrm{FC}_{0}$ & $\mathrm{FC}_{0}$ & $\mathrm{FC}_{0} \times 1.2$ & $\mathrm{FC}_{0} \times \mathbf{0 . 9}$ \\
\hline Shape factor for exponentially decreasing transmissivity (szm) & $\mathrm{SZM}_{0}$ & $\mathrm{SZM}_{0} \times 1.65$ & $\mathrm{SZM}_{0}$ & $\mathrm{SZM}_{0} \times 1.20$ \\
\hline Natural log of transmissivity ( $\mathrm{t} 0$ ) & $\mathrm{T}_{0-1}$ & $\mathbf{T}_{0-1} \times-2.25$ & $\mathbf{T}_{0-1} \times-1$ & $\mathbf{T}_{0-1} \times \pm 0.8$ \\
\hline Vertical, saturated hydraulic conductivity (xk0) & $\mathrm{XK}_{0-1}$ & $\mathrm{XK}_{0-1} \times 1.2$ & $\mathbf{X K}_{0-1} \times \mathbf{2}$ & $\mathrm{XK}_{0-1} \times \mathbf{9 . 2}$ \\
\hline Unsaturated zone time delay (td) & 60 & 40 & 300 & $7 ; 2,000$ \\
\hline Initial soil moisture deficit (sbar0) & 0.001 & 0.69 & 0.03 & 0.25 \\
\hline Groundwater loss rate (gw_loss) & 11 & 8.5, 11 & 11 & 11 \\
\hline
\end{tabular}

to an adjacent watershed rather than to the stream. By decreasing the CNs in the SWAT model, infiltration was increased and more water was made available for groundwater flow. Contributions of groundwater to streamflow were decreased by increasing the time required for groundwater to reach the stream and by increasing the amount of water in the shallow aquifer available for evaporation to the root zone to alleviate the soil moisture deficit. To account for the groundwater loss from the watershed in the SWAT model, recharge to the deep aquifer from all subbasins on the southern half of the watershed was increased to 20 percent of water percolation. Losses of groundwater from the northern half of the watershed were not allowed. This allowed water in the shallow aquifer to be removed from the topographical boundary of the watershed, consistent with the effects of the restrictive layer. In the SWAT model, groundwater moving to a deep, regional aquifer cannot directly contribute to streamflow.

WEBMOD simulations indicated that infiltration-excess overland runoff was the source of overly-large peak streamflows. The vertical, saturated hydraulic conductivity (xk0) of the soil varied in each hillslope, but in general was increased to about $1.2 \mathrm{~cm} / \mathrm{hr}$ (table 4 ). When simulated infiltration was increased, WEBMOD predicted that the mean depth to the water table in the watershed was within $1 \mathrm{~m}$ of the land surface. Field observations, in contrast, indicated the mean depth to the water table was about 2-3 m. To increase the thickness of the unsaturated zone, the average depth to the restrictive layer was increased from the default value of $1.5 \mathrm{~m}$ to $15 \mathrm{~m}$, which is similar to depths measured in the field. Simulations made after adjusting the depth to the restrictive layer produced streamflow hydrographs in which the magnitudes of the large peaks were similar to observed peaks. The simulated responses to small precipitation events still exceeded those in the observed hydrograph, while other such events were not reflected in simulation results. Commonly, the "missing" simulated streamflow peaks occurred early in the growing season when the model simulated excessive groundwater influx to the stream. To generate the small peaks in streamflow that were not simulated, percolating water was partitioned so that additional water was apportioned to lateral preferential flow to the stream. The fraction of potential infiltration that was preferentially routed to the saturated zone was also increased to further assist in generating the "missing" peaks. Additionally, the parameters controlling the exponential decrease of hydraulic conductivity ( $\mathrm{xk} 0$ ) and transmissivity (t0) with depth were decreased. These decreases caused more water to be retained 
in the root zone, which facilitated the generation of peaks as previously discussed.

To decrease the amount of groundwater influx to the stream in WEBMOD, a head-dependent loss parameter (gw_loss) was used to remove water from the shallow aquifer. By initiating groundwater losses in subbasins in the southern half of the watershed, simulated base-flow conditions matched observed base-flow conditions during periods of low streamflow. However, simulated base-flow streamflows during the growing season exceeded those observed during the same periods.

For the models to be considered accurate representations of hydrologic processes occurring at the Maryland watershed, it is expected that the statistical evaluations of model performance conform to the criteria of Moriasi and others (2007). In addition, the simulated actual evapotranspiration should be consistent with the long-term means noted previously. The performance of the models for October 1 , 1997, to September 30, 1998 (the water year of the simulation for which the annual streamflow was closest to the long-term mean annual streamflow of $270 \mathrm{~mm}$ reported by James and others [2003]), is illustrated in figure 2. Streamflow simulated by SWAT more closely matches the observed streamflow than the WEBMOD simulated streamflow (fig. 2). The statistics evaluated over the 8 -year calibration and validation periods, presented in table 5, confirm that the SWAT model performs better than the WEBMOD model. In all statistical evaluations for the validation period, however, the performance of both models can be considered "good."

The continuity between the observed and simulated massbalance components was ensured throughout the calibration process. Mean annual observed precipitation was $1,076 \mathrm{~mm}$ during the calibration period, which was drier than the $1,120 \mathrm{~mm}$ mean calculated from the 19 years of input precipitation data. Mean annual observed streamflow during the calibration period was $294 \mathrm{~mm}$, indicating that although precipitation during the period was less than the long-term mean annual value, more water was entering the stream than is indicated by the long-term mean annual streamflow of $270 \mathrm{~mm}$. Mean annual streamflow simulated for the calibration period by the SWAT model corresponded to the drier-than-normal climate and generated a mean annual simulated streamflow of $234 \mathrm{~mm}$, about $60 \mathrm{~mm}$ less than the mean annual observed streamflow for the calibration period. WEBMOD however, produced a mean annual streamflow of $305 \mathrm{~mm}$. These differences in model simulation results are evident when considering the PBIAS statistics in table 5, which indicate that SWAT underpredicts and WEBMOD overpredicts streamflow. After calibration, both models simulated mean annual actual evapotranspiration values similar to the reference evapotranspiration of $770 \mathrm{~mm}$ reported by Sloto (2002). SWAT simulated a mean annual evapotranspiration of $769 \mathrm{~mm}$, and WEBMOD simulated $748 \mathrm{~mm}$. Parameters related to permeability of the confining unit were adjusted to approximate a loss of $20 \mathrm{~mm} /$ year from the shallow aquifer to an adjacent watershed. Mean annual simulated groundwater losses from the watershed were
$17 \mathrm{~mm}$ in SWAT and $25 \mathrm{~mm}$ in WEBMOD during the calibration period, and $21 \mathrm{~mm}$ and $25 \mathrm{~mm}$, respectively, for the validation period. The "good" statistical values and the continuity between simulated and observed mass balances confirmed the calibration of both the SWAT and WEBMOD models at the Maryland watershed.

\section{The Indiana Watershed}

There were large differences in the performances of the initial SWAT and WEBMOD models developed for the Indiana watershed. As in the calibration of the SWAT model for the Maryland watershed, CNs for the Indiana SWAT model were decreased to allow more infiltration because the initial Indiana model produced peak streamflows exceeding those observed. Attempts were made to incorporate tile drains into the SWAT model for Indiana. However, analysis of simulation results indicated an insufficient lag time of tile flows into the stream. As Green and others (2006) note, the new version of this model, SWAT2005, is able to better reproduce the effects of tile drains on streamflow. To account for the influence of tile drains on streamflow with the SWAT2000 version, it was necessary to decrease the lateral traveltime and slope length of soils for individual HRUs to produce the desired peaks. The initial simulations indicated that the storm runoff was reaching the watershed outlet too quickly. Therefore, the parameter controlling how much water was retained by the channel, the surface-runoff lag coefficient (SURLAG), was reduced by onehalf to increase the amount of time required for water to reach the watershed outlet. Implicitly, this reduction could represent an accounting for the influence of stream-channel sinuosity on simulated streamflow, which is often lost during model preprocessing due to the coarse resolution of DEMs. Following these adjustments, the magnitude and temporal distribution of streamflow peaks closely resembled observed streamflow. The parameters controlling the influence of groundwater on streamflow, ALPHA_BF and GW_DELAY, required minor adjustments and consisted of increasing the time required for groundwater to reach the stream and increasing the amount of water available from the shallow aquifer to the root zone to alleviate the soil moisture deficit (REVAPMN). The resulting model was able to reliably reproduce streamflow and could be termed a "good" model, as indicated by the statistics in table 6 .

The initial WEBMOD model developed for the Indiana watershed was the only model to produce a positive NSE value from initial parameter input values. Improvements to model performance were made by assigning values to the s_satpref_zmax and s_satpref_zmin parameters that allow the model to simulate lateral preferential flow through the saturated zone, which implicitly accounts for the influence of tile drains. Additional minor adjustments to the s_theta_fc, t 0 , and $\mathrm{xk} 0$ parameters were made to decrease the rate at which water reached the saturated zone. Following these changes, model performance increased and produced statistics similar to the calibrated SWAT model. 


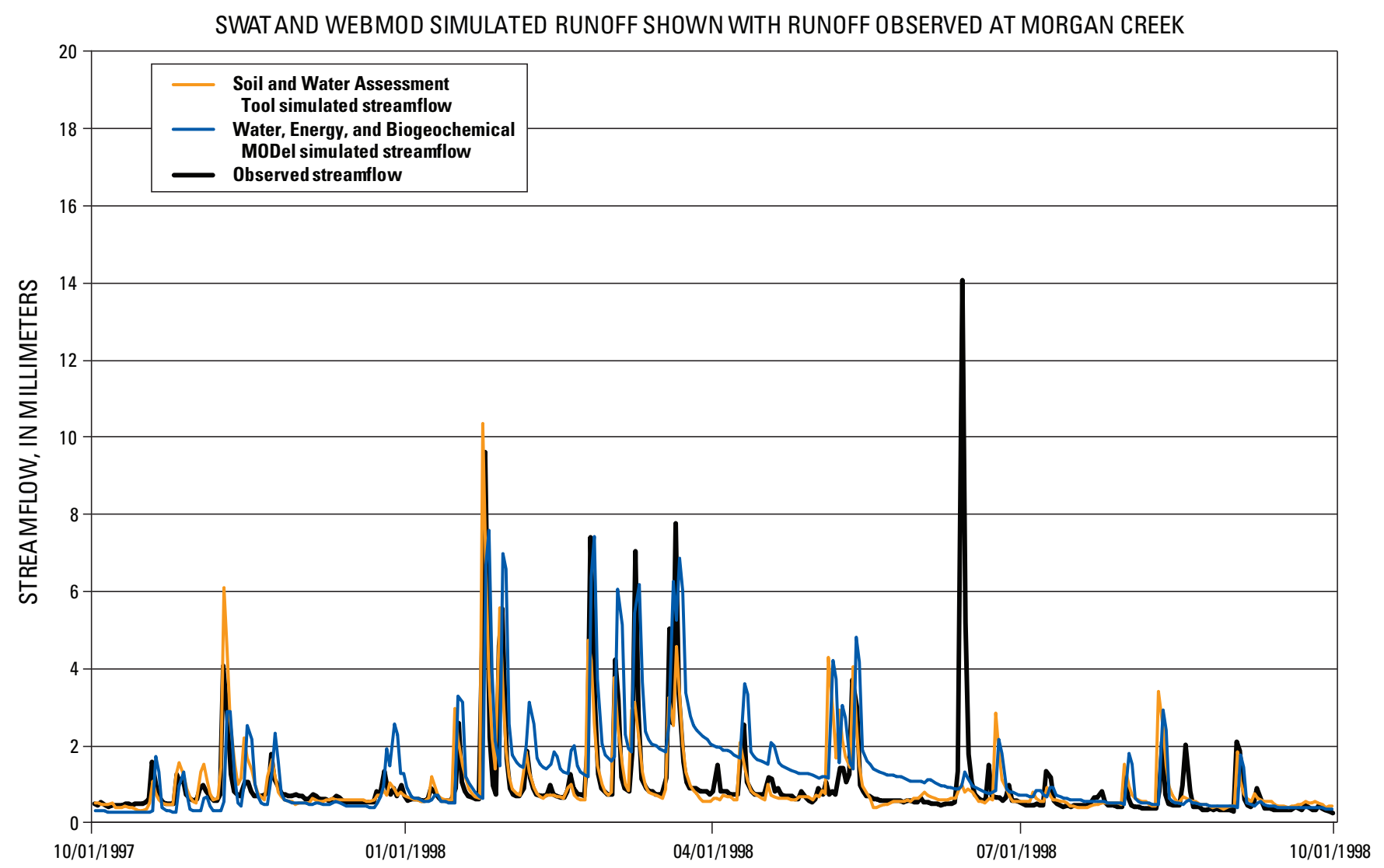

Figure 2. Observed and simulated streamflow in the Maryland watershed for water year 1998. Streamflow (millimeters) was determined as the quotient of streamflow (cubic meters per second) divided by basin area (square kilometers).

Table 5. Statistical evaluation of calibrated and validated Soil and Water Assessment Tool (SWAT) and Water, Energy, and Biogeochemical MODel (WEBMOD) models for the Maryland watershed.

\begin{tabular}{lccccc}
\hline \multirow{2}{*}{$\begin{array}{c}\text { Model evaluation } \\
\text { statistics }\end{array}$} & \multicolumn{2}{c}{ Calibrated } & & \multicolumn{2}{c}{ Validated } \\
\cline { 2 - 3 } \cline { 5 - 6 } & SWAT & WEBMOD & SWAT & WEBMOD \\
\hline Nash-Sutcliffe efficiency & 0.75 & 0.59 & & 0.84 & 0.67 \\
Ratio of the root mean square to the standard deviation of the observed data & 0.5 & 0.64 & 0.4 & 0.57 \\
Percent bias & 7.43 & -3.98 & 0.84 & -3.95 \\
\hline
\end{tabular}


The SWAT and WEBMOD models developed for the Indiana watershed were the best performing models of the study. Annual streamflow was most similar to the mean annual streamflow during the September 30, 1997, to October 1, 1998, water year, and figure 3 illustrates the performance of models during that water year. As the statistics in table 6 indicate, the calibrated models can be considered "good" models. The mean annual precipitation for the calibration period was $1,105 \mathrm{~mm}$, and the mean annual streamflow equaled $383 \mathrm{~mm}$. From the PBIAS statistics, it is clear that SWAT overpredicts $(410 \mathrm{~mm})$ mean annual streamflow, whereas WEBMOD underpredicts $(300 \mathrm{~mm})$ it. The differences in simulated streamflow are translated into the simulated evapotranspiration for each model. SWAT produced a mean annual evapotranspiration of $647 \mathrm{~mm}$ and WEBMOD produced $722 \mathrm{~mm}$. The performance of both models was similar during the validation period and confirmed that both models were "good."

\section{The Nebraska Watershed}

Developing calibrated models for the Nebraska watershed proved to be the most difficult. The initial simulations from both SWAT and WEBMOD not only did not produce large peaks in streamflow when those peaks actually occurred but produced large peaks when only base-flow conditions were present. Most of the observed peaks that the model did not simulate occurred during the winter months, most likely resulting from precipitation or snowmelt draining from a frozen land surface. Adjustments were made to the WEBMOD parameters controlling snowmelt timing to help reproduce the "missing" peaks. Parameters specific to the methods controlling water movement once it enters the soil were then adjusted in SWAT and WEBMOD.

To reduce the size of the simulated runoff peaks, changes were made in the SWAT parameters to increase infiltration. Changes included reducing the $\mathrm{CN}$, increasing the available water capacity of the soil (SOL_AWC), increasing the hydraulic conductivity of the soil (SOL_K), and increasing the percentage of pore volume in the soil available for preferential flow to the saturated zone (ICRK) (table 3). Following these changes, it was evident that an increase in streamflow peak duration was needed. Due to the coarseness of the DEM, the modeled stream channel is more linear than the actual channel; thus, water in the stream was reaching the outlet too quickly. The influence of this more sinuous stream channel on simulated streamflow was implicitly accounted for by decreasing, by 75 percent, the surface-runoff lag coefficient (SURLAG),

SWAT AND WEBMOD SIMULATED RUNOFF SHOWN WITH RUNOFF OBSERVED AT SUGAR CREEK NEAR PALESTINE, INDIANA

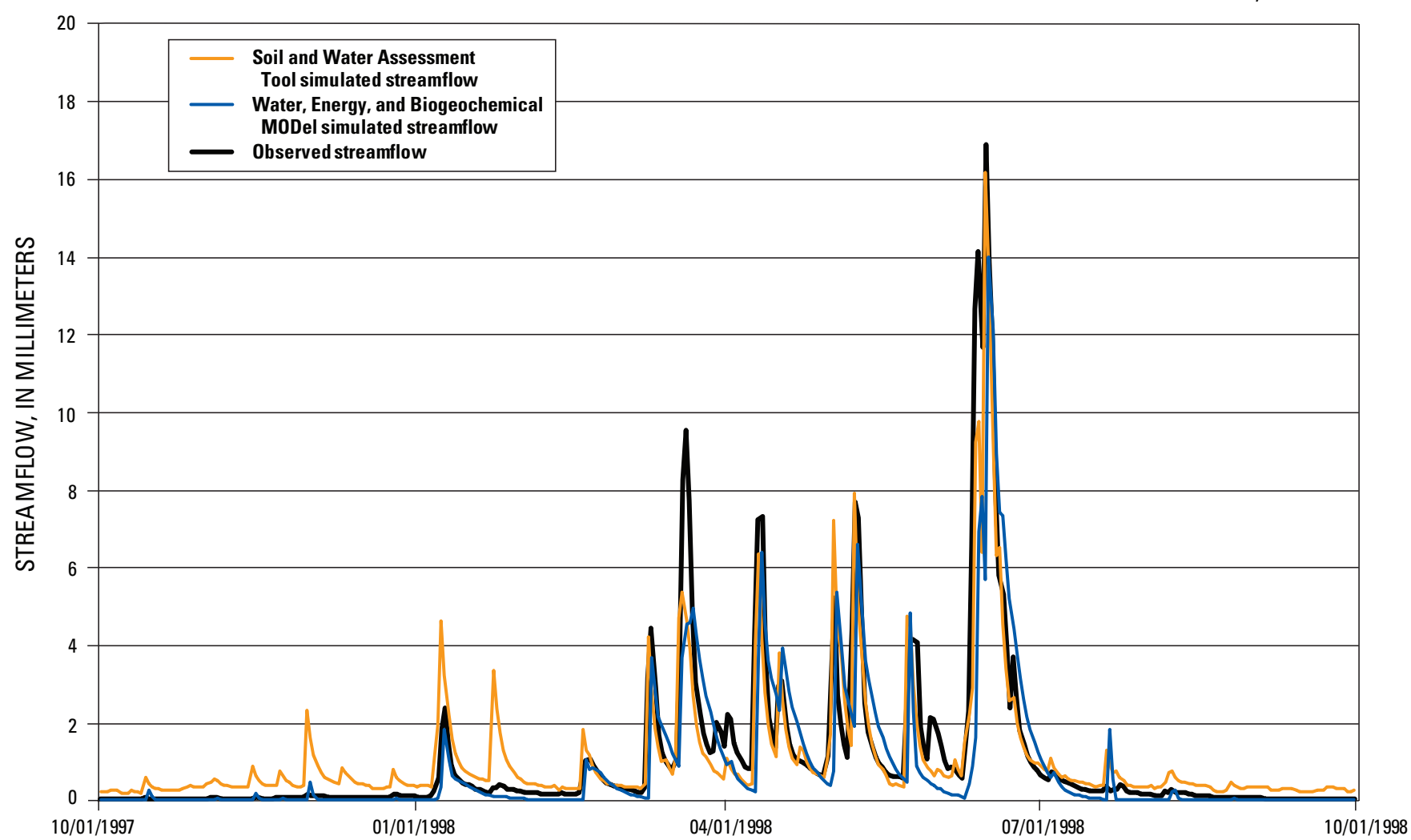

Figure 3. Observed and simulated streamflow in the Indiana watershed for water year 1998. Streamflow (millimeters) was determined as the quotient of streamflow (cubic meters per second) divided by basin area (square kilometers). 
Table 6. Statistical evaluation of calibrated and validated Soil and Water Assessment Tool (SWAT) and Water, Energy, and Biogeochemical MODel (WEBMOD) models for the Indiana watershed.

\begin{tabular}{lrrrrr}
\hline \multirow{2}{*}{ Model evaluation statistics } & \multicolumn{2}{c}{ Calibrated } & & \multicolumn{2}{c}{ Validated } \\
\cline { 2 - 5 } \cline { 5 - 6 } & \multicolumn{1}{c}{ SWAT } & WEBMOD & \multicolumn{2}{c}{ SWAT } & WEBMOD \\
\hline Nash-Sutcliffe efficiency & 0.78 & 0.77 & & 0.65 & 0.79 \\
Ratio of the root mean square to the standard deviation of the observed data & 0.47 & 0.47 & 0.59 & 0.45 \\
Percent bias & -6.98 & 21.81 & -13.38 & 0.24 \\
\hline
\end{tabular}

which controls the time required for water received by the stream to leave the watershed. To account for the effects of the perched water tables in the headwaters of the watershed, the lateral traveltime and slope length of the soils were decreased. Improvements in the model's ability to match the base-flow conditions of the stream were made by increasing the time required for water leaving the soil profile to reach the stream (ALPHA_BF and GW_DELAY).

The performance of the Nebraska WEBMOD model was improved by enabling more infiltration. The parameters controlling the log-normal decreases of hydraulic conductivity (szm) and transmissivity (t0) with depth were adjusted. An additional benefit of these changes was that more water was available for groundwater flow, and simulation results better matched the observed perennial contribution of groundwater to the stream. In addition, 20 to 50 percent of water leaving the root zone was routed to the stream as lateral preferential flow through the unsaturated zone.

The resulting performances of the calibrated Nebraska models were considerably poorer than that of the models for the Maryland and Indiana watersheds (table 7). Neither of the Nebraska models could be considered "good" models, but both were "satisfactory" according to the criteria described by Moriasi and others (2007). An example of streamflow simulated by SWAT and WEBMOD for a water year in which annual streamflow was closest to mean annual streamflow is illustrated in figure 4 . The ability of the models to conform to the mass balance of the system could improve the confidence in the parameter sets for each model. Mean annual precipitation for the calibration period was $691 \mathrm{~mm}$, and mean annual observed streamflow was $95 \mathrm{~mm}$. The mean annual streamflow simulated by the two models was in near agreement: $95 \mathrm{~mm}$ by the SWAT model and $92 \mathrm{~mm}$ by WEBMOD. The mean actual evapotranspiration from the SWAT model was $579 \mathrm{~mm}$; WEBMOD's result was $602 \mathrm{~mm}$. Both of these values are nearly $100 \mathrm{~mm}$ greater than that reported by Dugan and Zelt (2000) for Nebraska. However, the estimate of $500 \mathrm{~mm}$ of evapotranspiration was derived from a simple mass-balance calculation that limited evapotranspiration based on the availability of soil water and considered a mean annual precipitation of $609 \mathrm{~mm}$. The additional $82 \mathrm{~mm}$ of precipitation received during the calibration period could be expected to alleviate the soil moisture deficit and allow for the higher simulated values of evapotranspiration. This conclusion does not make the models acceptably reliable, but their ability to reproduce observed streamflow should allow for the processes governing streamflow contributions to be realized. The difficulties of calibrating the Nebraska model could be associated with the hydrologic complexity of the modeled watershed; the models had to account for a spatially variable climate, seasonally frozen soils, and groundwater contributions from perched and regional systems.

\section{Hydrologic Processes in Agricultural Watersheds Identified Using Precipitation-Runoff Models}

Once the models were calibrated it was possible to examine the different hydrologic processes by which both SWAT and WEBMOD conveyed water to a stream. The calibrated models introduced water into hillslopes by different means and yet generated streamflow through similar processes. By examining how each process contributed to streamflow, a better understanding of the hydrologic processes occurring could be achieved.

The conceptual understanding of the hydrology of the Maryland watershed indicated that groundwater flow was the largest annual source of streamflow, and as table 8 indicates, the simulation results for the validation period confirm this. In SWAT and in WEBMOD, lateral flow contributes nearly equal percentages to annual streamflow. The streamflow peaks that correspond to these lateral flows could actually represent the peak retardation resulting from the multitude of manmade ponds in the watershed. In general, it can be stated that, on an annual basis, groundwater constitutes the majority of stream water.

The influence of the different methods of accounting for soil moisture at the Maryland watershed is evident in figure 5. Due to the increased potential for runoff with shallow water tables implicit in the TOPMODEL-based WEBMOD, the responsiveness of the groundwater system to precipitation is better realized. Conceptually, peaks of runoff generated from precipitation were believed to be due primarily to infiltration excess runoff. However, WEBMOD results indicate that lateral preferential flow through the unsaturated zone was the primary means of conveying stormwater to the stream. 
Table 7. Statistical evaluation of calibrated and validated Soil and Water Assessment Tool (SWAT) and Water, Energy, and Biogeochemical MODel (WEBMOD) models for the Nebraska watershed.

\begin{tabular}{lcccccc}
\hline \multicolumn{1}{c}{ Model evaluation statistics } & \multicolumn{2}{c}{ Calibrated } & & \multicolumn{2}{c}{ Validated } \\
\cline { 2 - 3 } \cline { 5 - 6 } & SWAT & WEBMOD & & SWAT & WEBMOD \\
\hline Nash-Sutcliffe efficiency & 0.57 & 0.50 & & 0.32 & 0.55 \\
$\begin{array}{l}\text { Ratio of the root mean square to the standard deviation of } \\
\quad \text { the observed data }\end{array}$ & 0.65 & 0.70 & & 0.82 & 0.66 \\
Percent bias & -0.18 & 3.72 & & 10.23 & -2.78 \\
\hline
\end{tabular}

SWAT AND WEBMOD SIMULATED RUNOFF SHOWN WITH RUNOFF OBSERVED AT MAPLE CREEK NEAR NICKERSON, NE

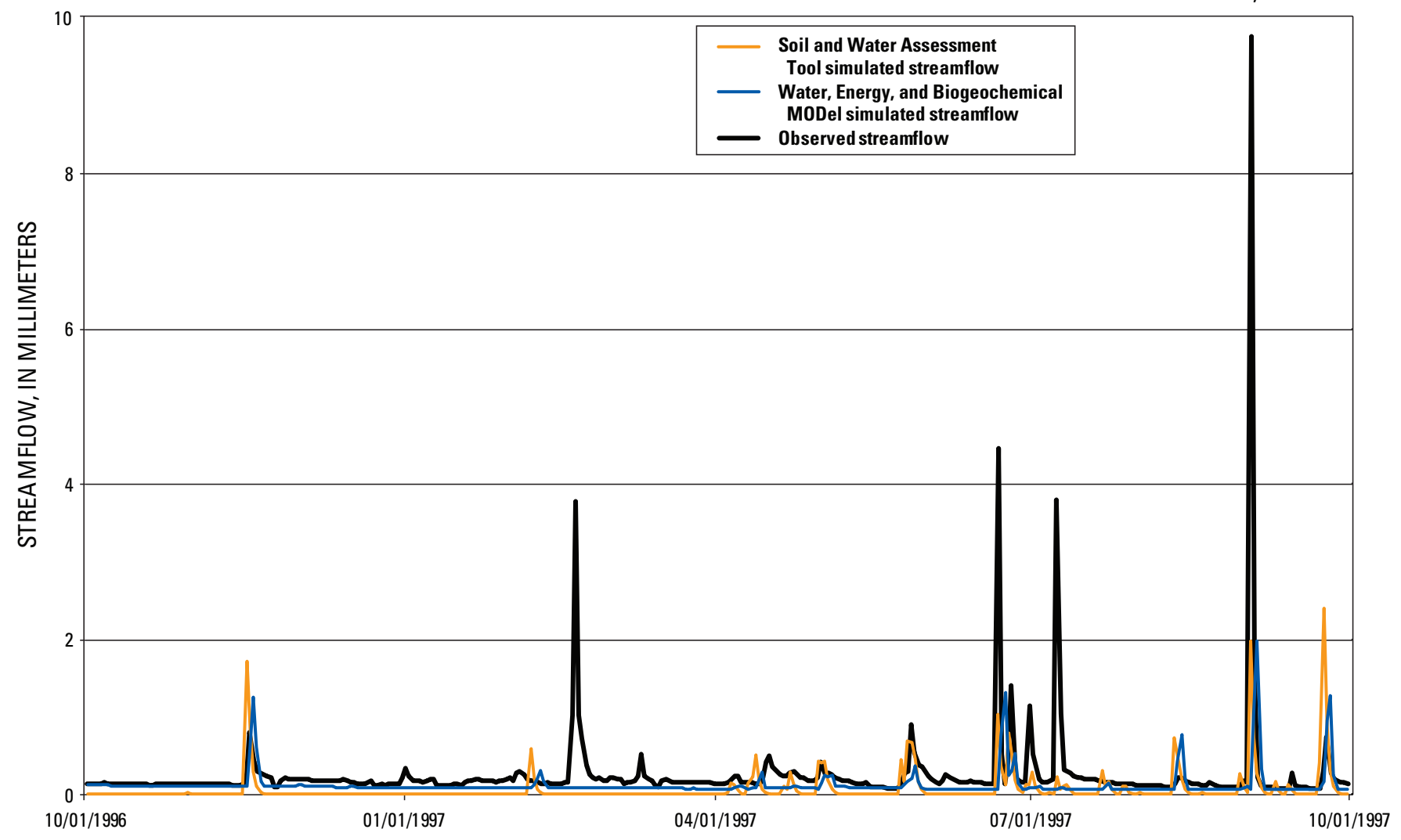

Figure 4. Observed and simulated streamflow in the Nebraska watershed for water year 1997. Streamflow (millimeters) was determined as the quotient of streamflow (cubic meters per second) divided by basin area (square kilometers). 
Table 8. Contributions to streamflow from Soil and Water Assessment Tool (SWAT) and Water, Energy, and Biogeochemical MODel (WEBMOD) simulations for the validation period.

[-, not calculated in the model]

\begin{tabular}{|c|c|c|c|c|c|}
\hline State & $\begin{array}{l}\text { Infiltration } \\
\text { excess runoff } \\
\text { (percent) }\end{array}$ & $\begin{array}{l}\text { Saturation } \\
\text { excess runoff } \\
\text { (percent) }\end{array}$ & $\begin{array}{l}\text { Unsaturated } \\
\text { lateral pref- } \\
\text { erential flow } \\
\text { (percent) }\end{array}$ & $\begin{array}{c}\text { Saturated } \\
\text { lateral pref- } \\
\text { erential flow } \\
\text { (percent) }\end{array}$ & $\begin{array}{l}\text { Groundwater } \\
\text { flow (percent) }\end{array}$ \\
\hline \multicolumn{6}{|c|}{ WEBMOD } \\
\hline Maryland & 12 & 2 & 23 & 0 & 63 \\
\hline Indiana & 12 & 1 & 12 & 50 & 25 \\
\hline Nebraska & 23 & 2 & 19 & 0 & 56 \\
\hline \multicolumn{6}{|c|}{ SWAT } \\
\hline & $\begin{array}{l}\text { Direct runoff } \\
\text { (percent) }\end{array}$ & & $\begin{array}{l}\text { Lateral flow } \\
\text { (percent) }\end{array}$ & & $\begin{array}{l}\text { Groundwater } \\
\text { flow (percent) }\end{array}$ \\
\hline Maryland & 22 & - & 25 & - & 53 \\
\hline Indiana & 46 & - & 30 & - & 24 \\
\hline Nebraska & 28 & - & 54 & - & 18 \\
\hline
\end{tabular}

This unsaturated lateral preferential flow could be contained within the direct runoff produced by the SWAT model. The $\mathrm{CN}$ simply partitions water between that which enters the stream and water that enters the soil matrix; therefore, SWAT is unable to explicitly account for lateral preferential flow in the unsaturated zone. This could account for the underprediction of the SWAT model indicated in figure 5; the percolating water, unable to contribute to streamflow, simply alleviates the soil moisture deficit.

Annual flows from tile drains at the Indiana watershed were thought to contribute most of the streamflow. In the SWAT model, it was assumed that tile-drain flow could be represented by lateral flow; however, most of the streamflow was contributed by direct runoff, as noted in table 8 . Field observations indicated the presence of vertical cracks in the land surface, which could conduct direct runoff to the tile drains. Therefore, it is reasonable to assume that at least some of the direct runoff could be routed to the stream through the tile drains. With WEBMOD, preferential lateral flow from the saturated zone (tile drains) constituted most of the annual flow of the stream. Contributions to streamflow from groundwater in SWAT were similar in timing (fig. 6) and volume (table 8 ) to WEBMOD. The simulation results confirm that lateral preferential flow, predominantly from tile drains, is the major contributor to streamflow at the Indiana watershed.

The performance of the model for the Nebraska watershed was not as good as the models for the Indiana and Maryland watersheds. This result was due, for the most part, to the high spatial variability of precipitation in this watershed; however, some conclusions can be made about the dominant hydrologic processes in Nebraska. Infiltration-excess runoff generated the largest simulated peaks in each model, and groundwater flow contributed to streamflow year-round (table 8, figure 7). The flows from perched water tables in the headwater parts of the watershed could be accounted for by the lateral flow in SWAT and by the lateral preferential flow through the unsaturated zone in WEBMOD.

\section{Limitations of Study and Needs for Future Research}

This study was limited principally because no chemical transport simulations were conducted. Different chemical species and concentrations have been shown to be indicative of hydrologic processes. For example, nitrate concentrations in groundwater can be correlated to nitrate concentrations observed at a watershed outlet if groundwater is a major component of streamflow. Results of these simulations could have been compared to chemicals measured in groundwater and at the watershed outlet. Once the hydrologic processes that are major sources of streamflow have been identified, the next step would be to determine if there were any relations between those processes and the applied agricultural chemicals.

Because both SWAT and WEBMOD can simulate chemical transport, these models could be used in any future efforts to link environmental processes to in-stream chemistry.

\section{Summary and Conclusions}

Agricultural chemical transport from point and nonpoint sources is one of the leading impairments to water quality in rivers and lakes. To alleviate the impairments induced by agricultural chemicals, much research has focused on improving the understanding of relations between application areas, the media through which the chemicals travel, and the receptor to which the chemicals are transported. Almost exclusively this transport is controlled by the hydrologic processes moving 

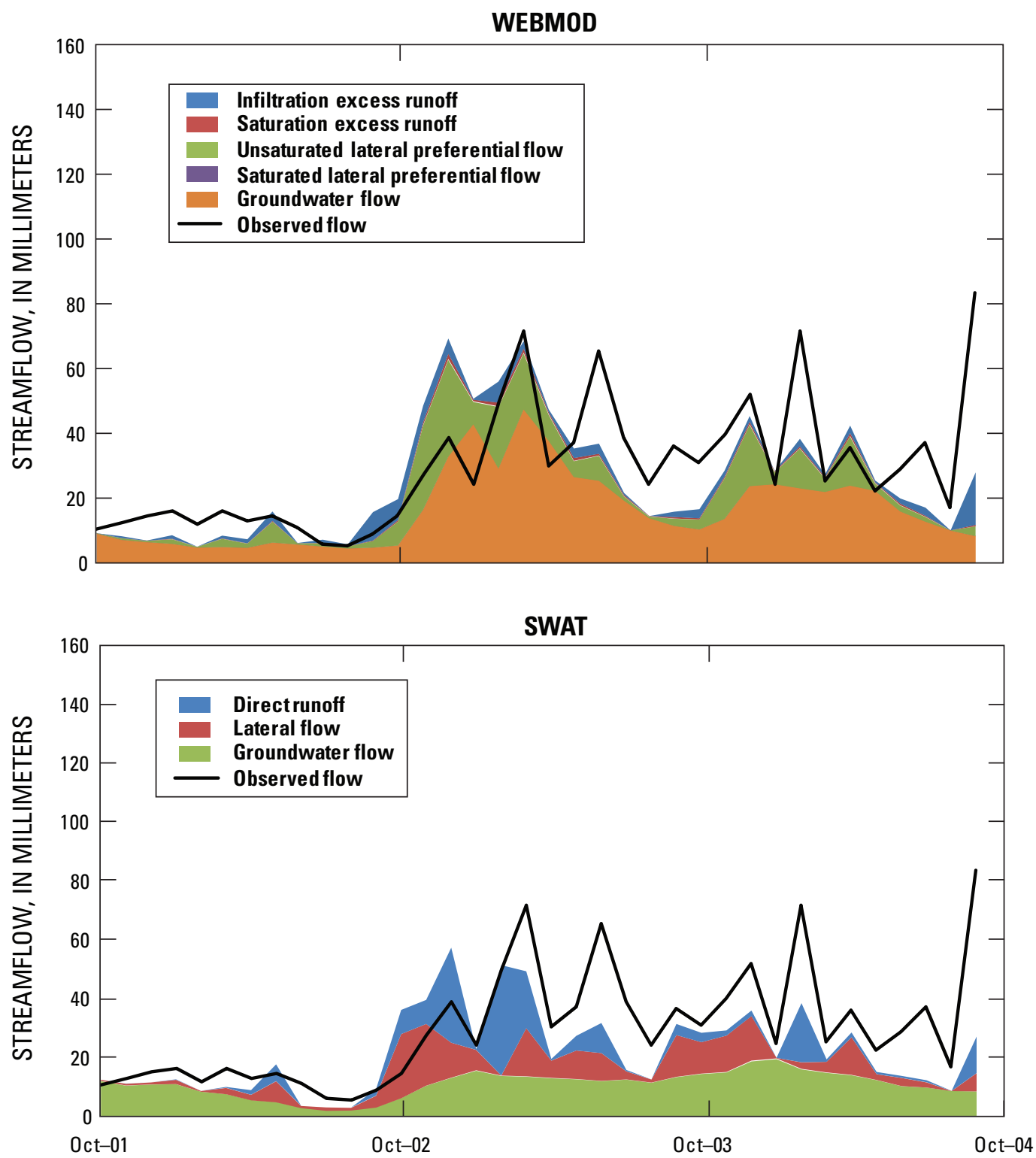

Figure 5. Contributions to streamflow from validated Soil and Water Assessment Tool (SWAT) and Water, Energy, and Biogeochemical MODel (WEBMOD) models for the Maryland watershed. 

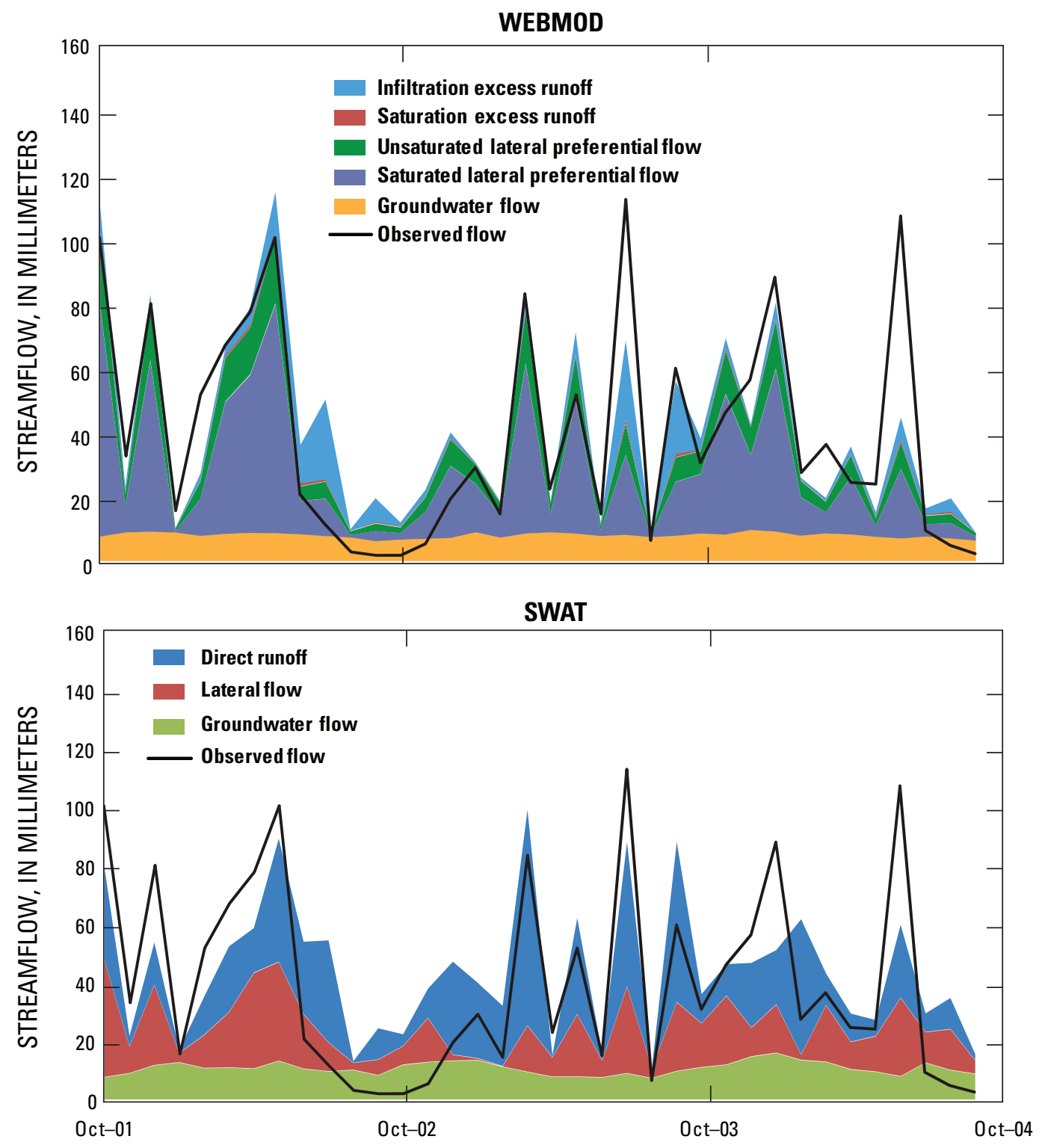

Figure 6. Contributions to streamflow from validated Soil and Water Assessment Tool (SWAT) and Water, Energy, and Biogeochemical MODel (WEBMOD) models for the Indiana watershed. 

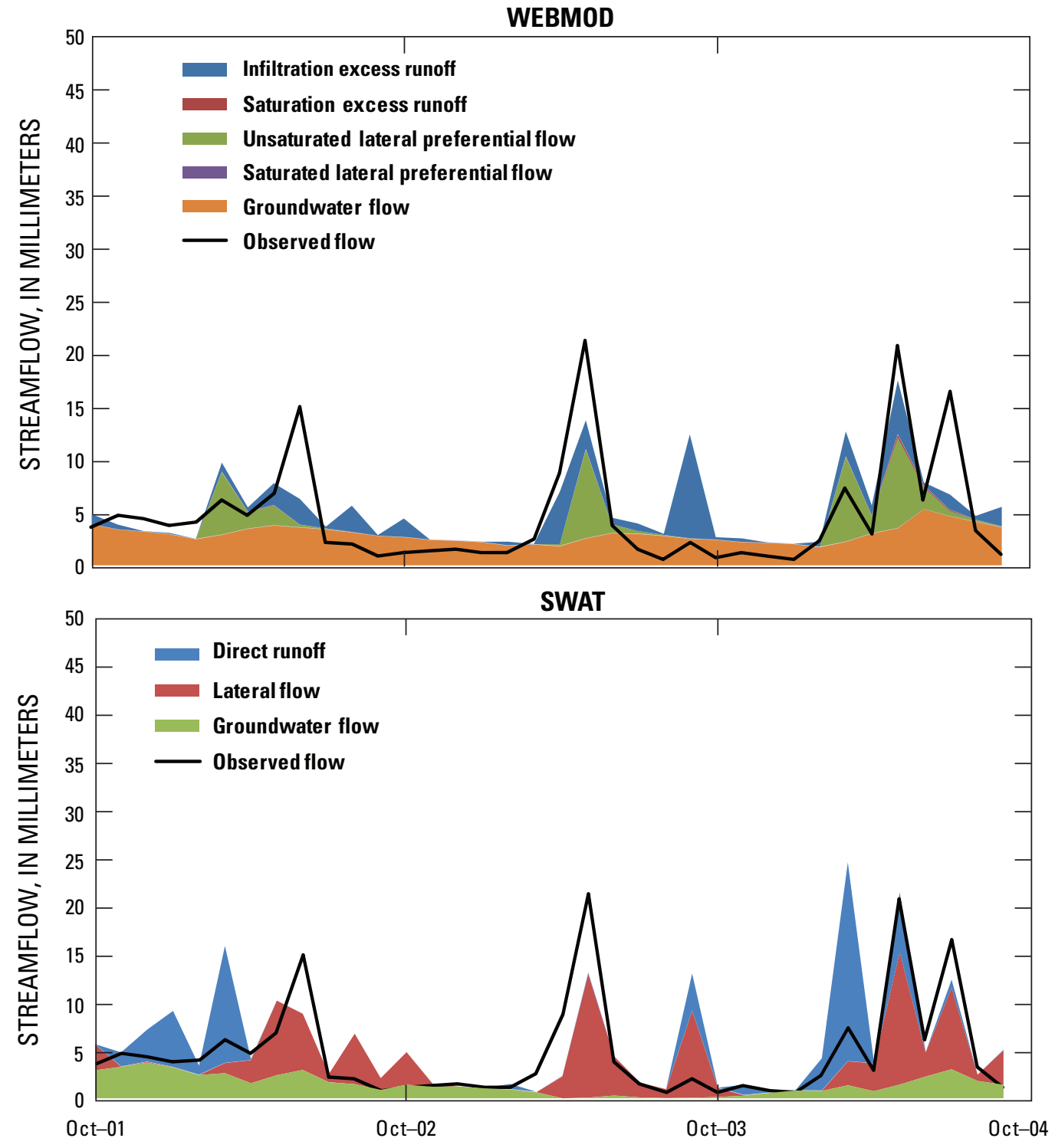

Figure 7. Contributions to streamflow from validated Soil and Water Assessment Tool (SWAT) and Water, Energy, and Biogeochemical MODel (WEBMOD) models for the Nebraska watershed. 
water through the environment. A conceptual model of the processes governing the movement of water can be developed on the basis of field observations. An alternative to a conceptual model - an alternative that can quantitatively describe the hydrologic processes controlling chemical transport-is a distributed precipitation-runoff model. Through such a model's ability to account for the spatial variability of hydrologic processes, a more quantitative understanding of agricultural chemical transport can be obtained.

This study used two precipitation-runoff models - the Soil and Water Assessment Tool (SWAT) and the Water, Energy, and Biogeochemical Budgets Model (WEBMOD) - to identify the hydrologic processes that move water through three different agricultural watersheds: the Maryland watershed, the Indiana watershed, and the Nebraska watershed. The hydrologic processes identified by the models were then compared to corresponding processes in the conceptual models developed at each watershed. Through this comparison, a realistic picture of the hydrologic system, in terms of the relative importance of different processes by which water was transported to the watershed outlet, was obtained. The SWAT and WEBMOD models were manually calibrated to improve their performance statistics. Although the parameters in each model represented different hydrologic theory, each model commonly required adjustments to better simulate the same hydrologic processes. In general, the parameters governing the infiltration of water through the root zone, the delay of groundwater movement from the saturated zone to the stream, and the timing of snowmelt required changing. Simulation results from validated models produced statistical values similar to those of the calibration period.

The SWAT and WEBMOD model results at each watershed conformed to each other and to the processes identified in each watershed's conceptual hydrology. In Maryland the conceptual understanding of the hydrology indicated groundwater flow was the largest annual source of streamflow; the simulation results for the validation period confirm this. The dominant source of water to the Indiana watershed was thought to be tile drains. Although tile drains were not explicitly simulated in the SWAT model, a large component of streamflow was received from lateral flow, which could be attributed to tile drains. Being able to explicitly account for tile drains, WEBMOD indicated water from tile drains constituted most of the annual streamflow in the Indiana watershed. The Nebraska models indicated annual streamflow was composed primarily of perennial groundwater flow and infiltration-excess runoff, which conformed to the conceptual hydrology developed for that watershed. The hydrologic processes represented in the parameter sets resulting from each model were comparable at individual watersheds but varied between watersheds. The models were unable to show, however, whether hydrologic processes other than those included in the original conceptual models were major contributors to streamflow.

\section{References Cited}

Beven, K.J., and Kirkby, M.J., 1979, A physically-based variable contributing area model of basin hydrology: Hydrological Science Bulletin, v. 24, p. 43-69.

Capel, P.D, McCarthy, K.A., and Barbash, J.E., 2008, National, holistic, watershed-scale approach to understand the sources, transport, and fate of agricultural chemicals: Journal of Environmental Quality, v. 37, no. 3, p. 983-993.

Carluer, Nadia, and De Marsily, G., 2004, Assessment and modeling of the influence of man-made networks on the hydrology of a small watershed-Implications for fast flow components, water quality, and landscape management: Journal of Hydrology, v. 285, p. 76-95.

Dugan, J.T., and Zelt, R.B., 2000, Simulation and analysis of soil-water conditions in the Great Plains and adjacent areas, Central United States, 1951-80: U.S. Geological Survey Water-Supply Paper 2427, 81 p.

Edwards, D.R., Daniel, T.C., Scott, H.D., Moore, Jr., P.A., Murdoch, J.F., and Vendrell, P.F., 1997, Effect of BMP implementation on storm flow quality of two northwestern Arkansas streams: Transactions of the American Society of Agricultural and Biological Engineers, v. 40, no. 5, p. 1311-1319.

Fenelon, J.M., and Moore, R.C., 1998, Transport of agrichemicals to ground and surface water in a small central Indiana watershed: Journal of Environmental Quality, v. 27, p. 884-894.

Fitzhugh, T.W., and Mackay, D.S., 2000, Impacts of input parameter spatial aggregation on an agricultural nonpoint source pollution model: Journal of Hydrology, v. 236, p. $35-53$.

Fredrick, B.S., Linard, J.I., and Carpenter, J.L., 2006, Environmental setting of Maple Creek watershed, Nebraska: U.S. Geological Survey Scientific Investigations Report 2006-5037, 22 p.

Green, C.H., Tomer, M.D., Di Luzio, M., and Arnold, J.G., 2006, Hydrologic evaluation of the Soil and Water Assessment Tool for a large tile-drained watershed in Iowa: Transactions of the American Society of Agricultural Engineers, v. 49 , no. 2 , p. $413-422$.

Hancock, T.C., and Brayton, M.J., 2006, Environmental setting of the Morgan Creek Basin, Maryland, 2002-04: U.S. Geological Survey Open-File Report 2006-1151, 28 p.

Hay, L.E., and McCabe, G.J., 2002, Spatial variability in water-balance model performance in the conterminous United States: Journal of the American Water Resources Association, v. 38, no. 3, p. 847-860. 
Hewlett, J.D., and Hibbert, A.R., 1967, Factors affecting the response of small watersheds to precipitation in humid areas, in Sopper, W.E., and Lull, H.W., eds., International Symposium on Forest Hydrology, The Pennsylvania State University, August 29-September 10, 1965: Oxford, Pergamon, p. 275-290.

Hyer, K.E., Hornberger, G.M., and Herman, J.S., 2001, Processes controlling the episodic streamwater transport of atrazine and other agrichemicals in an agricultural watershed: Journal of Hydrology, v. 254, p. 47-66.

James, R.W., Saffer, R.W., Pentz, R.H., and Tallman, A.J., 2003, Water resources data, Maryland, Delaware, and Washington, D.C., water year 2002: U.S. Geological Survey Water-Data Report MD-DE-DC-02-1, accessed February 10, 2005, at http://md.water.usgs.gov/publications/ md-de-02-1/

Lathrop, T.R., 2006, Environmental setting of the Sugar Creek and Leary Weber Ditch Basins, Indiana, 2002-04: U.S. Geological Survey Scientific Investigations Report 2006-5170, 27 p.

Leavesley, G.H., Restrepo, P.J., Markstrom, S.L., Dixon, M., and Stannard, L.G., 1998, The Modular Modeling System (MMS)_User's manual: U.S. Geological Survey Open-File Report 96-151, 142 p.

Leu, Christian, Singer, H., Muller, S.R., Schwarzenbach, R.P., and Stamm, C., 2005, Comparison of atrazine losses in three small headwater catchments: Journal of Environmental Quality, v. 34, p. 1873-1882.

Leu, Christian, Singer, H., Stamm, C., Muller, S.R., and Schwarzenbach, R.P., 2004, Simultaneous assessment of sources, processes, and factors influencing herbicide losses to surface water in a small agricultural catchment: Environmental Science and Technology, v. 38, p. 3827-3824.

McCuen, R.H, 1982, Guide to hydrologic analysis using SCS methods: Englewood Cliffs, New Jersey, Prentice-Hall, Inc., $160 \mathrm{p}$.

Meyer, P.D., Rockhold, M.L., and Gee, G.W., 1997, Uncertainty analyses of infiltration and subsurface flow and transport for SDMP sites: Washington, D.C., Nuclear Regulatory Research, U.S. Nuclear Regulatory Commission, Division of Regulatory Applications Office, NUREG/CR-6565, PNNL-11705.

Moore, I.D., Grayson, R.B., and Ladson, A.R., 1991, Digital terrain modeling-A review of hydrologic, geomorphological, and biological applications: Hydrologic Processes, v. 5, p. 3-30.
Moriasi, D.N., Arnold, J.G., Van Liew, M.W., Bingner, R.L., Harmel, R.D., and Veith, T.L., 2007, Model evaluation guidelines for systematic quantification of accuracy in watershed simulations: Transactions of the American Society of Agricultural and Biological Engineers, v. 50, no. 3, p. 885-900.

Moussa, Roger, Voltz, M. and Andrieux, P., 2002, Effects of spatial organization of agricultural management on the hydrological behaviour of a farmed catchment during flood events: Hydrological Processes, v. 16, p. 393-413.

National Research Council, 2002, Opportunities to improve the U.S. Geological Survey National Water-Quality Assessment Program: National Academic Press, Washington, D.C.

Neitsch, S.L., Arnold, J.G., Kinry, J.R., Williams, J.R., and King, K.W., 2002, Soil and water assessment tool theoretical documentation: Version 2000, Texas Water Resources Institute, College Station, Texas, accessed August 17, 2005 , at http://www.brc.tamus.edu/swat/doc.html

Parry, Roberta, 1998, Agricultural phosphorus and water quality-A U.S. Environmental Protection Agency perspective: Journal of Environmental Quality, v. 27, p. 258-261.

Schwarz, G.E., and Alexander, R.B., 1995, State soil geographic (STATSGO) data base for the conterminous United States: U.S. Geological Survey Open-File Report 95-449.

Shaffer, M.J., and Delgado, J.A., 2001, Field techniques for modeling nitrogen management, in Follett, R.F., and Hatfield, J.L., eds., Nitrogen in the environment-Sources, problems, and management: New York, Elsevier Science, p. $391-412$.

Sloto, R.A., 2002, Geohydrology and groundwater quality, Big Elk Creek Basin, Chester County, Pennsylvania, and Cecil County, Maryland: U.S. Geological Survey WaterResources Investigations Report 2002-4057, accessed August 18, 2005, at http://pa.water.usgs.gov/reports/wrir024057.pdf

Stone, W.W., and Wilson, J.T., 2006, Preferential flow estimates to an agricultural tile drain with implications for glyphosate transport: Journal of Environmental Quality, v. 35 , p. $1825-1835$.

U.S. Department of Agriculture, National Agricultural Statistics Service, 2002, National Agriculture Statistics Service's 1:100,000-Scale 2001 Cropland Data Layer, a cropspecific digital data layer for eastern Nebraska: USDA/ NASS Customer Service, Washington D.C.

U.S. Geological Survey, 1999, The National Hydrography Dataset: U.S. Geological Survey Fact Sheet 106-99, accessed May 7, 2006, at http://erg.usgs.gov/isb/pubs/ factsheets/fs10699.html 
U.S. Geological Survey, 2006, National Elevation Dataset (NED), accessed May 7, 2006 at URL: http://seamless.usgs. gov/

Vogelmann, J.E., Howard, S.M., Yang, L., Larson, C.L., Wylie, B.K., and Van Driel, N., 2001, Completion of the 1990s national land cover data set for the conterminous United States from Landsat Thematic Mapper data and ancillary data sources: Photogrammetric Engineering and Remote Sensing, v. 67, p. 650-652.

Webb, R.M.T., Wolock, D.M., Linard, J.I., and Wieczorek, M.E., 2006, The water, energy, and biogeochemical model (WEBMOD) - A TOPMODEL application developed within the Modular Modeling System: Proceedings of the 3d Federal Interagency Hydrologic Modeling Conference, Reno, Nevada, April 2-6, 2006.

Whipkey, R.Z., 1965, Subsurface stormflow from forested slopes: Bulletin of the International Association of Scientific Hydrology, v. 10, no. 2, p.74-85.

Publishing support provided by:

Denver Publishing Service Center

For more information concerning this publication, contact:

Director, USGS Colorado Water Science Center

Box 25046, Mail Stop 415

Denver, CO 80225

(303) 236-4882

Or visit the Colorado Water Science Center Web site at:

http://co.water.usgs.gov/ 


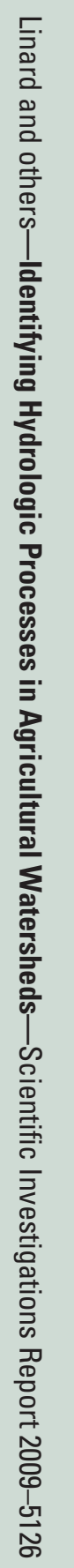

8 Printed on recycled paper 